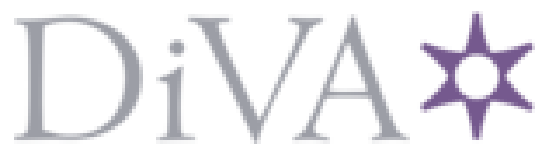

http://www.diva-portal.org

This is the published version of a paper published in Solar Energy.

Citation for the original published paper (version of record):

Duarte, W M., Paulinoc, T F., Pabond, J J., Sawalha, S., Machado, L. (2019)

Refrigerants selection for a direct expansion solar assisted heat pump for domestic hot water

Solar Energy, 184(May): 527-538

https://doi.org/10.1016/j.solener.2019.04.027

Access to the published version may require subscription.

N.B. When citing this work, cite the original published paper.

Permanent link to this version:

http://urn.kb.se/resolve?urn=urn:nbn:se:kth:diva-249947 


\title{
Refrigerants selection for a direct expansion solar assisted heat pump for domestic hot water
}

\author{
Willian M. Duarte a, b, *, Tiago F. Paulino ${ }^{c}$, Juan J.G. Pabon ${ }^{d}$, Samer Sawalha e ${ }^{\mathrm{e}}$ Luiz Machado ${ }^{\text {a }}$ \\ ${ }^{a}$ Post-Graduate Program in Mechanical Engineering, Federal University of Minas Gerais (UFMG), Belo Horizonte (MG), Brazil \\ ${ }^{\mathrm{b}}$ Department of Mechanical Engineering, University of Belo Horizonte (UNIBH), Belo Horizonte (MG), Brazil \\ ${ }^{c}$ Department of Materials Engineering, Federal Center of Technological Education of Minas Gerais (CEFET-MG), Belo Horizonte, Brazil \\ ${ }^{\mathrm{d}}$ Institute of Mechanical Engineering, Federal University of Itajubá (UNIFEI), Itajubá (MG), Brazil \\ e Department of Energy Technology, Royal Institute of Technology (KTH), Stockholm, Sweden
}

\section{A R T I C L E IN F O}

\section{Keywords:}

Alternative refrigerants

DX-SAHP

R1234yf

R290

R600a

R744

\begin{abstract}
A B S T R A C T
An important step during a project of a heat pump system is choosing a more suitable refrigerant. This paper presents a comparative study among refrigerants for a small direct expansion solar assisted heat pump (DX-SAHP). The mathematical model used in this study is presented in detail and validated from an experimental setup. The R134a is the reference and the refrigerants with low GWP are R290, R600a, R744 and R1234yf. The results show that R290 has better COP than others refrigerants for solar radiation between $300 \mathrm{~W} / \mathrm{m}^{2}$ and $700 \mathrm{~W} / \mathrm{m}^{2}$, as well as for environment temperature between $10^{\circ} \mathrm{C}$ and $35^{\circ} \mathrm{C}$. On the other hand, for solar radiation less than $50 \mathrm{~W} /$ $\mathrm{m}^{2}$, the R134a has better COP than R290. TEWI (Total Equivalent Warming Impact) analysis indicates that the indirect emission is the most important effect, and then, the TEWI results almost followed the COP outcome. A parametric analysis was conducted to evaluate the influence of the $\mathrm{CO}_{2}$ emission factor for producing electricity. In countries with higher emission factor, the refrigerant with the best COP has the best TEWI. The influence of wind speed and ambient temperature in COP of a DX-SAHP using R290 were more relevant in low solar radiation.
\end{abstract}

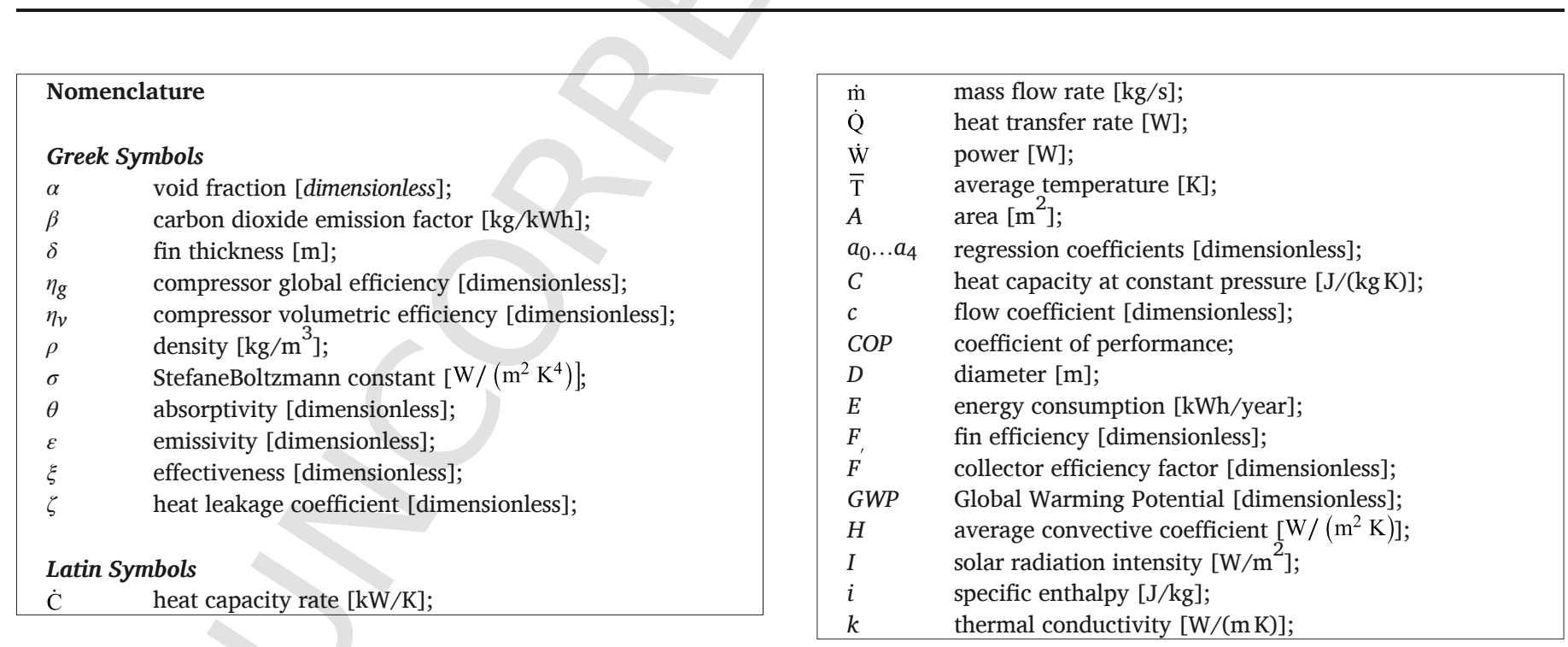

\footnotetext{
* Corresponding author at: Federal University of Minas Gerais, Av. Antnio Carlos, 6627, Pampulha, 31270-901, Belo Horizonte (MG), Brazil. Email address: willianmoreiraduarte@gmail.com (W.M. Duarte)
} 


\begin{tabular}{|c|c|}
\hline$L$ & leakage rate in the system [kg/year]; \\
\hline$l$ & length $[\mathrm{m}]$; \\
\hline$m$ & mass $[\mathrm{kg}]$; \\
\hline$N$ & lifetime of the system [years]; \\
\hline$n$ & rotation speed $[1 / \mathrm{s}]$; \\
\hline$N T U$ & number of transfer units [dimensionless]; \\
\hline$P$ & pressure $[\mathrm{Pa}]$; \\
\hline$q_{0}$ & $\begin{array}{l}\text { difference between the emissive power from a black } \\
\text { body at the ambient air temperature and the emissive } \\
\text { power from the sky }\left[\mathrm{W} / \mathrm{m}^{2}\right] \text {; }\end{array}$ \\
\hline$R$ & heat capacity rate ratio[dimensionless]; \\
\hline$r$ & compressor pressure ratio [dimensionless]; \\
\hline$S$ & net radiation absolved $\left[\mathrm{W} / \mathrm{m}^{2}\right]$; \\
\hline$T$ & temperature $[\mathrm{K}]$; \\
\hline$t$ & time $[\mathrm{s}]$; \\
\hline TEWI & total equivalent warming impact $\left[t \mathrm{CO}_{2}-e q\right]$; \\
\hline$U$ & overall heat transfer coefficient $\left[\mathrm{W} /\left(\mathrm{m}^{2} \mathrm{~K}\right)\right]$; \\
\hline$u$ & wind speed \\
\hline$V$ & volume $\left[\mathrm{m}^{3}\right]$; \\
\hline$V_{c}$ & compressor displacement volume $\left[\mathrm{m}^{3}\right]$ \\
\hline$W$ & work $[\mathrm{J}]$; \\
\hline$w$ & distance between the tubes $[\mathrm{m}]$; \\
\hline \multicolumn{2}{|c|}{ Common subscripts } \\
\hline 1 & compressor inlet; \\
\hline 2 & compressor outlet; \\
\hline 3 & expansion valve inlet; \\
\hline 4 & expansion valve outlet; \\
\hline$a$ & ambient or environment; \\
\hline$c c$ & coaxial condenser \\
\hline$c d$ & condenser; \\
\hline стр & compressor; \\
\hline ed & expansion device; \\
\hline$e V$ & evaporator; \\
\hline$i$ & inner of the tube; \\
\hline$i c$ & immersed condenser \\
\hline$L$ & liquid; \\
\hline $\max$ & maximum; \\
\hline $\min$ & minimum; \\
\hline$o$ & outer of the tube; \\
\hline re & refrigerant; \\
\hline$s$ & for insetropic compression process; \\
\hline$t$ & $\operatorname{tank}$ \\
\hline$V$ & vapor; \\
\hline$w$ & water; \\
\hline$w f$ & final water property; \\
\hline$w i$ & initial water property; \\
\hline win & water condenser inlet; \\
\hline wout & water condenser outlet; \\
\hline
\end{tabular}

\section{Introduction}

A heat pump for heating water reduces significantly the electric energy consumption because this device uses environment available energy. In special, a solar assisted heat pump receives energy by convection and condensation of the water vapor in the atmospheric air, as well as the energy directly from the sun's rays. This larger amount of energy to the evaporator of heat pump produces an increase in the evaporating temperature, decrease the compressor work and thus increase the heat pump COP of the system. Improvement of COP in a DX-SAHP is discussed in the literature (Ito et al., 1999; Kong et al., 2011; Sun et al., 2014).
An important step in the heat pump design is choosing a good refrigerant. The refrigerant needs to have several characteristics, such as: (a) non-toxic and non-flammable; (b) easy leak detection; (c) suitable thermodynamic properties; (d) high chemical stability in the refrigeration system; (e) miscible in the lubricating oil; (f) compatibility with refrigeration system materials; (g) low cost; and (h) low environmental impact. Sarbu (2014) presents as the most important characteristics in the selection of a refrigerant, the low environmental impact in terms of global warming, and the capacity of the refrigerant to operate with high efficiency. In a DX-SAHP, different refrigerants have been used, such as R12 (Ito et al., 1999; Chaturvedi and Shen, 1984; Chaturvedi and Abazeri, 1987), R22 (Kong et al., 2011; Kuang and Wang, 2006; Xu et al., 2009), R134a (Sun et al., 2014, 2018a, 2013), R744 (Islam et al., 2012; Faria et al., 2016; Oliveira et al., 2016), R410A (Kong et al., 2017), R407C (Mohamed et al., 2017) and R433A (Paradeshi et al., 2018).

Several studies have been carried out to find suitable refrigerant options. Chata et al. (2005) analyzed the COP of a DX-SAHP with different refrigerants. In this study, the condensing temperature was set at $60{ }^{\circ} \mathrm{C}$ and the evaporating temperature between $0{ }^{\circ} \mathrm{C}$ and $20^{\circ} \mathrm{C}$. The refrigerants analyzed were R12, R22, R134a, R404A, R407C and R410A. The results showed the best COP for R12, R22 and R134a respectively, but the difference between R12 and R134a was only $3 \%$ on average. In this work, the authors have also performed a comparative analysis between CFC (R12), HCFC (R22) and four HFCs (R134a, R404A, R407C and R410A). In this case, only the first two refrigerants do not have zero ODP (ozone depletion potential). The ODP control requirement was proposed in the Montreal protocol (UNEP, 2006).

Nowadays, in addition to zero ODP, it is necessary for refrigerants to have low GWP (global warming potential), which is not reached by any of the analyzed refrigerants above. The greenhouse gases control was proposed in the Kyoto protocol (Bodansky, 1993). The following studies consider the requirements of zero ODP and low GWP.

Makhnatch and Khodabandeh (2014b) present a comparative study among R410A, R290, R1270, R152a and R1234yf for a $30 \mathrm{~kW}$ capacity air/water heat pump system designed for residential heating application. The R410A was the reference and the others refrigerant had GWP less than 150. The results showed the propane (R290) with the most adequate option in terms of COP and Life Cycle Climate Performance (LCCP).

Ghoubali et al. (2014) developed a comparative analysis among R407C, R290 and R1234yf using models of a water to water heat pump of small to medium capacity, for simultaneous heating and cooling for a residence. The model proposed was validated experimentally for the R407C on a heat pump with $15 \mathrm{~kW}$ heating capacity. The authors concluded that propane is the best option due to a low environmental impact, best SCOP (seasonal coefficient of performance) and commercial availability of equipment.

Botticella and Viscito (2015) implemented an air to water residential heat pump mathematical model to produce a comparative analysis between the refrigerants R290 and R1234yf. The analyses were performed for different operational conditions and the results showed the best performance with the propane.

Chaichana et al. (2003) analyzed natural refrigerant to replace R22 in a solar assisted heat pump for domestic water heating applications. The refrigerants analyzed were R290, R600, R600a, R1270, R717 and R744. The results showed R717 with the best option for the conditions evaluated.

Sarbu (2014) presented a review about the replacement of non-ecological refrigerants from vapor compression-based refrigeration, air-conditioning and heat pump systems. The paper highlights as good options the hydrocarbons (such as R290, R600a, R1150 and R1270) because of the low environmental impact and suitable performance, and the natural refrigerants (such as R717 and R744). However, for the 
first one group, it was listed the toxicity as a problem. It also reports that for the same application it is possible to have more than one good refrigerant. Furthermore, the use of the refrigerant with low environmental impact requires others efforts. Finally, the possibility of the use R1234yf is highlighted.

The increasing use of the R600a in a domestic refrigeration would be highlighted. UNEP (2015) discuss that R134a and R600a are the most useful refrigerants used in the domestic refrigeration nowadays. The document also reports the tendency to increase the use of R600a and it is projected that the R600a will be used in $75 \%$ of the new refrigerators in 2020.

Based on the literature review, the improvement of the COP due to the solar radiation in a DX-SAHP is presented in Ito et al. (1999), Kong et al. (2011), Sun et al. (2014). It is also presented that a DX-SAHP operates with better COPs than a non-solar assisted heat pump (Sun et al., 2015) and it is widely used to heat water (Omojaro and Breitkopf, 2013). In the current days, it is an important step to improve the use of the DX-SAHP by choosing a suitable refrigerant. There are several studies to find suitable refrigerant options. However, there is none that makes a comparison between refrigerants with low GWP for a DX-SAHP. Most of the analysis assume a fixed efficiency of the compressor for all refrigerants. Nevertheless, in this work, a different efficiency was used for each refrigerant based in data of commercial compressors available in the international market. In this paper, the selection of refrigerants to replace the R134a in a DX-SAHP is carried out. In this work, a DX-SAHP for heating water for bath for a single family (four people) is considered. The consumption of domestic hot water adopted was 501/person/ day and the storage temperature adopted is $65{ }^{\circ} \mathrm{C}$. For that purpose, a mathematical model is presented to compare technically the performance of the refrigerants. After that, the TEWI (total equivalent warming impact) analysis is developed to examine the environmental impact. Finally, the better refrigerant can be selected. Before using the model for these purposes, it was validated from experimental results.

This paper is organized as following: In Section 2, it is presented the refrigerants with low GWP selected for this work. The experimental setup used in the validation of the model is presented in Section 3. The mathematical model is described in details in Section 4. The results of the mathematical validation, comparison of energetic and environmental system performances using the new refrigerants, and a parametric analysis are presented in Section 5 . The conclusion ends the paper.

\section{Selecting refrigerants candidates}

The fluids selected for this work are the refrigerants R290, R600a, R744 and R1234yf. These refrigerants will be compared to R134a, which is widely used in DX-SAHP (Hawlader et al., 2001; Chyng et al., 2003; Chata et al., 2005; Chow et al., 2010; Fernández-Seara et al., 2012; Sun et al., 2014; Moreno-Rodriguez et al., 2013; Deng and Yu, 2016; Diniz, 2017; Kong et al., 2018a; Kong et al., 2018b). The R290 was selected because of the discussions presented in Sarbu (2014), Makhnatch and Khodabandeh (2014b), Ghoubali et al. (2014) and Botticella and Viscito (2015). In addition, the R290 is used by many heat pump manufactures (Palm, 2008) and it can work at high evaporating temperature (Chaichana et al., 2003). Despite of the flammability of the R290, the DX-SAHP of this work is a small equipment and it will be installed in a open vented location. Selection of the refrigerant R600a, as discussed by UNEP (2015), is due to the refrigerant circuit to be small, equivalent to a domestic refrigerator. Furthermore, the R600a presents a lower noise levels, which is important for domestic products, and the compressor for this refrigerant has a good efficiency (Palm, 2008). The selection of the R744 is based on the discussions presented in Sarbu $(2014,2012,2016)$.In addition, the use of the R744 in a heat pump for heating water is highlighted in Ma et al. (2013) by the good match between the water temperature profile in applications with conventional heaters. Finally, the choice of R1234yf is based on analyses presented in Makhnatch and Khodabandeh (2014b), Ghoubali et al. (2014), Botticella and Viscito (2015), Duarte et al. (2018) for different points of operation of the system. In addition, the R1234yf is always an ecological alternative (Sarbu, 2014). Also, the R1234yf has been used as a drop-in replacement of the R134a in different systems (Lee and Jung, 2012; Belman-Flores et al., 2017) and the COP values are quite similar, but the R134a COP is slightly better. Table 1 shows the characteristics and properties given by ASHRAE (2013) for the five selected refrigerants.

Despite of the studies pointing out R717 as the best option for solar assisted heat pumps (Chaichana et al., 2003) and some theoretical studies indicating some hydrocarbon and hydro-fluro-carbons mixtures for DX-SAHP (Sarbu, 2014; Paradeshi et al., 2018; Mohanraj et al., 2018), these options will be not included in this work due the lack of commercial components for the heating capacity discussed in this work.

\section{Experimental setup}

The model validation is the process to evaluate whether or not the mathematical model can be used to predict, with some tolerance, the physical parameter of interest. After being approved in the validation procedure, the mathematical model is ready to be used in place of experimental tests, to simulate different scenarios and operating conditions, and produce reliable output data. The main advantage of the use of a mathematical model is the fact that it can be used to simulate conditions that may be difficult to assess through experimental tests. Additionally, the costs comprised in the simulations are generally smaller than the ones involved in the experimental tests, and the results are mostly generated in a shorter time.

The model was validated using the results of the experiments performed and presented by Diniz (2017) using a R134a DX-SAHP. The experimental setup is shown in Fig. 1. This heat pump is composed of a tank to store hot water with $200 \mathrm{~L}$, a hermetic reciprocating compressor manufactured by Embraco, model FFU100HAK. This compressor has a fixed rotation speed $(3500 \mathrm{rpm})$ and the swept volume is $7.95 \mathrm{~cm}^{3} / \mathrm{rev}$. The evaporator or collector has $1.65 \mathrm{~m}^{2}$ of area and thickness of $1 \mathrm{~mm}$, the evaporator tube has length, inner diameter and outer diameter of $17.28 \mathrm{~m}, 8.73 \mathrm{~mm}$ and $9.53 \mathrm{~mm}$, respectively, and the distance between the tubes is $103 \mathrm{~mm}$. The collector is painted with a black paint with emissivity and solar absorptivity of 0.95 . The evaporator has an angle of $30^{\circ}$ with the horizontal. A thermostatic expansion valve (TEV) is used to maintain the superheat at the outlet of the evaporator around $7.4^{\circ} \mathrm{C}$. The DX-SAHP can operate with two different condensers: an immersed condenser and a coaxial condenser. The immersed condenser is basically a $4.5 \mathrm{~m}$ horizontal copper tube, without fin, folded into the tank bottom, and have the same diameters of the evaporator tube. The design of this condenser is detailed de-

Table 1

Information of the refrigerants candidates.

\begin{tabular}{llllll}
\hline Refrigerant & R134a & R290 & R600a & R744 & R1234yf \\
\hline Normal boiling point $\left[{ }^{\circ} \mathrm{C}\right]$ & -26 & -42 & -12 & -78 & -29.4 \\
$\begin{array}{l}\text { Critical temperature }\left[{ }^{\circ} \mathrm{C}\right] \\
\text { Critical pressure }[\mathrm{kPa}]\end{array}$ & 101 & 96.68 & 134.7 & 30.98 & 94.7 \\
Liquid density at $25^{\circ} \mathrm{C}$ & 4059 & 4247 & 3640 & 7377 & 3382 \\
$\left.\quad 1 \mathrm{~kg} / \mathrm{m}^{3}\right]$ & 1207 & 492.1 & 549.9 & 705.1 & 1092 \\
Vapour density at $25{ }^{\circ} \mathrm{C}$ & 32.37 & 20.64 & 9.123 & 242.8 & 37.94 \\
$\quad\left[\mathrm{~kg} / \mathrm{m}^{3}\right]$ & 0 & 0 & 0 & 0 & 0 \\
$\begin{array}{l}\text { ODP } \\
\text { GWP 100 years }\end{array}$ & 1370 & 20 & 20 & 1 & 4 \\
Atmospheric lifetime [years] & 13.4 & 0.041 & 0.016 & $>50$ & 0.029 \\
ASHRAE 34 - Safety code & A1 & A3 & A3 & A1 & A2L \\
\hline
\end{tabular}




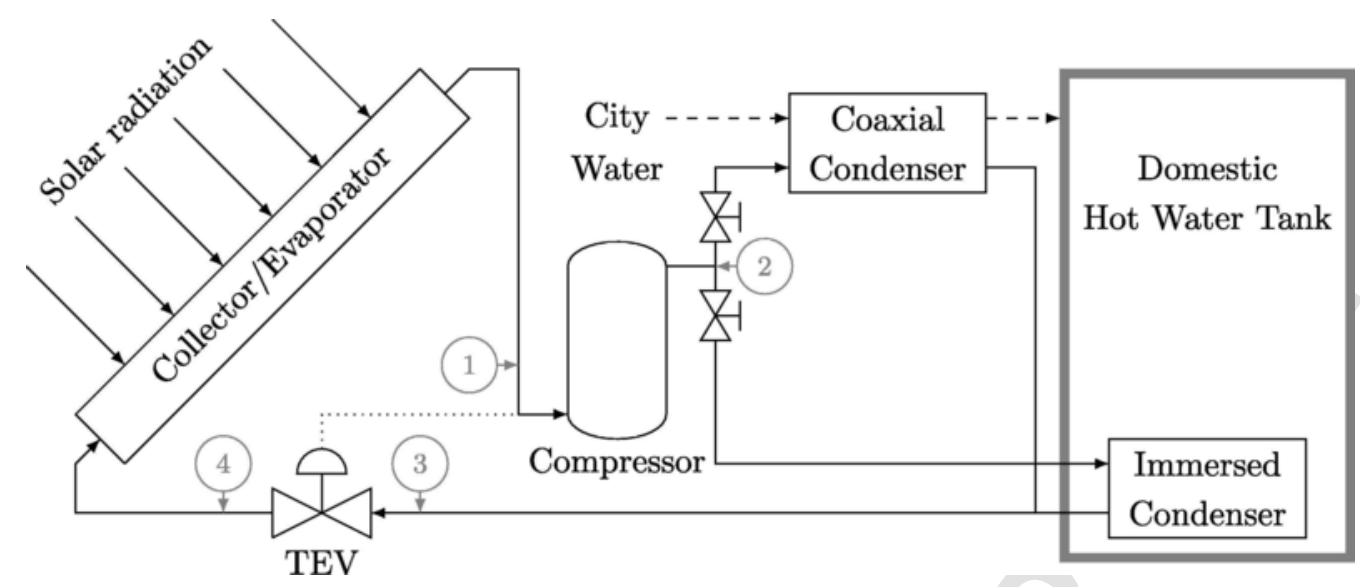

Fig. 1. Experimental setup used in the validation.

scribed by Reis (2012). The coaxial condenser is a $5.5 \mathrm{~m}$ concentric counterflow heat exchanger. The inner copper tube has diameters of $4.76 \mathrm{~mm}$ and $6.35 \mathrm{~mm}$ and the outer tube $11.11 \mathrm{~mm}$ and $12.5 \mathrm{~mm}$. The details of the design of the coaxial condenser are presented by Diniz (2017). In this system, only one condenser is used at a time.

The measured coefficient of performance (COP) of the heat pump is obtained from the following equation:

$$
C O P=\frac{\rho_{w} C_{w} V_{w}\left(\mathrm{~T}_{w i}-\mathrm{T}_{w f}\right)}{\mathrm{W}_{c m p}}
$$

where $T_{w i}$ is the initial water temperature, $T_{w f}$ is the final water temperature, $W_{c m p}$ is the compressor energy consumption, $V_{w}$ is the volume of water inside the tank, $C_{w}$ is the water heat capacity and $\rho_{w}$ is the water density. Thermocouples K-type, with standard uncertainty of $1{ }^{\circ} \mathrm{C}$, were installed at different points of DX-SAHP to measure the temperature of R134a and water. The consumption of the compressor was measured using a wattmeter with uncertainty of $1 \%$. The volume of the tank was measured using 20 liter graduated container. The density and heat capacity was calculated using the Equation Engineering Solver (EES) software at mean temperature. The combined standard of COP was calculated according to BIPM et al. (2008). The average combined standard uncertainty of measured COP was $5 \%$.

Additionally, other parameters was measured presented by (Diniz, 2017). To measure the solar radiation perpendicular to the ground and perpendicular to the solar evaporator, it was used two pyranometers with $5 \%$ of uncertainty. The wind velocity was measured by a digital vane anemometer, with range of $0-30 \mathrm{~m} / \mathrm{s}$ and uncertainty of $3 \%$. The direction of wind was checked using a windsock and the anemometer pointed into the direction of the wind. A digital psychrometer was used to measure dew point temperature $\left( \pm 2^{\circ} \mathrm{C}\right)$ and ambient temperature $\left( \pm 1^{\circ} \mathrm{C}\right)$. To evaluate the atmospheric pressure, it was used the data from Pampulha weather station which is located $1.7 \mathrm{~km}$ distant from the laboratory. The historical and real time weather data are available in INMET website. To measure volumetric water flow of the coaxial condenser, in the range of $0.5-11$ per minute, it was used 11 graduated container with resolution of $50 \mathrm{ml}$ and a timer.

Diniz (2017) made 20 experimental tests using the DX-SAHP to heat 2001 of water from ambient temperature to approximately $45{ }^{\circ} \mathrm{C}$, considering indoor and outdoor environments. These tests were made to compare the system using both condensers. These tests are presented in Tables 2 and 3 . In these tables, $T_{a}, P_{a t m}, \phi, I, u, T_{w i}, T_{w f}$ and Time represent the ambient temperature, atmospheric pressure, relative humidity, solar radiation in the evaporator plane, wind speed, initial water temperature, final water temperature and time of operation, respectively.

\section{Development of the DX-SAHP model}

In order to select the refrigerants for the DX-SAHP, a quasi-steady-state model was developed using the EES. For the heat exchangers, a lumped model was used and the pressure drop was considered negligible. The heat loss and pressure drop in the ducts between components were assumed inappreciable and for the inventory charge of the refrigerant, the pipeline was considered two meters long. The following sections describe the modelling equation for each component of the heat pump.

\subsection{Evaporator/solar collector}

The heat transfer rate received by the refrigerant in the evaporator is given by:

$\dot{\mathrm{Q}}_{e v}=\dot{\mathrm{m}}_{r e}\left(\mathrm{i}_{1}-\mathrm{i}_{4}\right)$

Table 2

Experimental performance of a DX-SAHP using a immersed condenser.

\begin{tabular}{|c|c|c|c|c|c|c|c|c|c|c|}
\hline & Date & $T_{a}$ & $P_{a t m}$ & $\phi$ & $I$ & $u$ & $T_{w i}$ & $T_{w f}$ & Total & Measured \\
\hline Test & mm-dd-yy & $\left({ }^{\circ} \mathrm{C}\right)$ & $(\mathrm{kPa})$ & $(\%)$ & $\left(\mathrm{W} / \mathrm{m}^{2}\right)$ & $(\mathrm{m} / \mathrm{s})$ & $\left({ }^{\circ} \mathrm{C}\right)$ & $\left({ }^{\circ} \mathrm{C}\right)$ & time & $\mathrm{COP}$ \\
\hline 1 & 01-07-17 & 28.2 & 91.9 & 48 & 0 & 0 & 32.8 & 44.9 & $3: 45$ & $2.31 \pm 0.12$ \\
\hline 2 & $01-14-17$ & 26.1 & 91.8 & 74 & 0 & 0 & 32.6 & 45.3 & $4: 00$ & $2.27 \pm 0.11$ \\
\hline 3 & 01-18-17 & 26.0 & 91.8 & 59 & 0 & 0 & 31.5 & 45.2 & $4: 30$ & $2.29 \pm 0.11$ \\
\hline 4 & 01-20-17 & 26.6 & 91.9 & 47 & 0 & 0 & 30.9 & 45.9 & $5: 00$ & $2.30 \pm 0.11$ \\
\hline 5 & 01-24-17 & 27.3 & 91.8 & 56 & 0 & 0 & 32.2 & 45.2 & $4: 15$ & $2.27 \pm 0.11$ \\
\hline 6 & $02-04-17$ & 29.8 & 91.8 & 51 & 482 & 0.72 & 29.6 & 44.8 & $3: 00$ & $2.88 \pm 0.14$ \\
\hline 7 & $02-11-17$ & 26.4 & 91.8 & 58 & 346 & 0.86 & 28.1 & 45.3 & $4: 15$ & $2.58 \pm 0.12$ \\
\hline 8 & 02-16-17 & 33.2 & 92.2 & 30 & 520 & 0.99 & 29.8 & 46.1 & $3: 45$ & $2.64 \pm 0.13$ \\
\hline 9 & $02-17-17$ & 32.6 & 91.8 & 32 & 671 & 1.53 & 29.3 & 44.8 & $3: 00$ & $2.80 \pm 0.14$ \\
\hline 10 & 02-18-17 & 31.6 & 92.0 & 39 & 807 & 1.25 & 29.4 & 45.5 & $3: 00$ & $2.91 \pm 0.15$ \\
\hline
\end{tabular}


Table 3

Experimental performance of a DX-SAHP using a coaxial condenser.

\begin{tabular}{|c|c|c|c|c|c|c|c|c|c|c|}
\hline & Date & $T_{a}$ & $P_{a t m}$ & $\phi$ & $I$ & $u$ & $T_{w i}$ & $T_{w f}$ & Total & Measured \\
\hline Test & mm-dd-yy & $\left({ }^{\circ} \mathrm{C}\right)$ & $(\mathrm{kPa})$ & $(\%)$ & $\left(\mathrm{W} / \mathrm{m}^{2}\right)$ & $(\mathrm{m} / \mathrm{s})$ & $\left({ }^{\circ} \mathrm{C}\right)$ & $\left({ }^{\circ} \mathrm{C}\right)$ & time & $\mathrm{COP}$ \\
\hline 11 & $01-12-17$ & 27.1 & 91.5 & 55 & 0 & 0 & 27.3 & 44.8 & $05: 30$ & $2.37 \pm 0.12$ \\
\hline 12 & 01-13-17 & 26.6 & 91.5 & 68 & 0 & 0 & 26.3 & 45.3 & $06: 03$ & $2.25 \pm 0.12$ \\
\hline 13 & $01-16-17$ & 24.9 & 91.7 & 72 & 0 & 0 & 25.0 & 46.0 & 07:03 & $2.25 \pm 0.11$ \\
\hline 14 & $01-17-17$ & 26.1 & 91.5 & 58 & 0 & 0 & 25.1 & 46.0 & $06: 50$ & $2.35 \pm 0.12$ \\
\hline 15 & 01-19-17 & 26.5 & 91.7 & 61 & 0 & 0 & 25.8 & 45.5 & $06: 27$ & $2.31 \pm 0.12$ \\
\hline 16 & 01-23-17 & 29.7 & 91.9 & 42 & 421 & 0.52 & 27.6 & 46.7 & $04: 47$ & $2.56 \pm 0.13$ \\
\hline 17 & $01-25-17$ & 32.9 & 92.0 & 37 & 709 & 0.86 & 28.7 & 47.4 & $03: 53$ & $2.72 \pm 0.14$ \\
\hline 18 & $01-25-17$ & 32.7 & 92.0 & 38 & 758 & 0.95 & 29.3 & 47.3 & $03: 47$ & $2.64 \pm 0.14$ \\
\hline 19 & $01-27-17$ & 32.5 & 92.1 & 32 & 629 & 1.16 & 29.0 & 45.9 & 03:40 & $2.68 \pm 0.14$ \\
\hline 20 & $01-28-17$ & 31.2 & 92.1 & 34 & 811 & 1.36 & 29.0 & 47.8 & 03:40 & $2.47 \pm 0.13$ \\
\hline
\end{tabular}

where $\mathrm{m}$ is the mass flow rate, $i$ is the specific enthalpy and the numeric subscripts are related to the points shown in Fig. 1.

The energy gain in a flat plate collector in steady-state condition is given by:

$\dot{\mathrm{Q}}_{e v}=\mathrm{A}_{e v} \mathrm{~F}^{\prime}\left[\mathrm{S}-\mathrm{U}_{e v}\left(\overline{\mathrm{T}}_{r e}-T_{a}\right)\right]$

where $A_{e v}$ is the area of evaporator/ collector, $F$ is the collector efficiency factor, $S$ is the net radiation absorbed per unit of area, $U_{e v}$ is overall heat loss coefficient, $\overline{\mathrm{T}}_{r e}$ is the average temperature of the refrigerant fluid and $T_{a}$ is the ambient air temperature.

The collector efficiency, proposed by Duffie and Beckman (2013), and considering that the resistance to heat flow due the bond between the collector plate and tube can be neglected, is given by:

$\mathrm{F}^{\prime}=\frac{1}{w U_{e v}}\left\{\frac{1}{\mathrm{U}_{e v}\left[D_{o}+\mathrm{F}\left(\mathrm{w}-D_{o}\right)\right]}+\frac{1}{\pi D_{i} H_{i}}\right\}^{-1}$

where the distance between the tubes is $w$, the fin efficiency is $F$, the diameter is $D$ and the convective coefficient is $H$. The subscripts $i$ and $o$ represent, respectively, the inner and outer of the tube.

The fin efficiency can be evaluated by:

$\mathrm{F}=\frac{\tanh \left[\left(\mathrm{w}-D_{o}\right) / 2 \sqrt{\mathrm{U}_{e v} /(k \delta)}\right]}{\left(\mathrm{w}-D_{o}\right) / 2 \sqrt{\mathrm{U}_{e v} /(k \delta)}}$

where $k$ is the thermal conductivity and $\delta$ is the fin thickness.

The net radiation absorbed is evaluated by Kong et al. (2017) using the fowling equation:

$\mathrm{S}=\theta I-\varepsilon \mathrm{q}_{0}$

where the absorptivity is $\theta$, the solar radiation intensity normal to evaporator is $I$, the emissivity is $\varepsilon$ and $q_{0}$ is the difference between the emissive power from a black body and from the sky.

The overall heat loss coefficient proposed by Kong et al. (2011) is determined by:

$\mathrm{U}_{e v}=H_{o}+4 \varepsilon \sigma T_{a}^{3}$

where $\sigma$ is the StefaneBoltzmann constant.

To evaluated the average convective heat transfer inside the evaporator tube $\left(H_{i}\right)$ the local convective heat transfer is numerically integrated with respect to enthalpy. The local convective heat transfer (h) is obtained using the correlation proposed by Shah (2017) for two phase flow and the correlation proposed by Gnielinski (1976) for single phase flow. To calculated the external convective heat transfer $\left(H_{O}\right.$ ), it was used the collection of correlations presented by Neils and Klein (2009) for free convection in a inclined flat plate, if Péclet number is lower than 100 , and correlation for forced convection in a flat plate, if Péclet number is grater or equal to 100 .

\subsection{Compressor}

The compression process is modeled as isentropic and the mass flow rate in a constant rotation speed reciprocating compressor is given by Eq. (8) (Hanlon, 2001).

$\dot{\mathrm{m}}_{r e}=\rho_{1} n V_{\mathrm{c}} \eta_{v}$

where $\rho_{1}$ is the refrigerant density at the compressor inlet, $n$ is the rotation speed, $V_{c}$ is the compressor displacement volume and $\eta_{v}$ is the volumetric efficiency.

The electric power consumption in the compressor is evaluated as by Hanlon (2001):

$\dot{\mathrm{W}}_{c m p}=\frac{\dot{\mathrm{m}}_{r e}\left(\mathrm{i}_{2}-\mathrm{i}_{1}\right)}{\eta_{g}}$

where $\eta_{g}$ is the overall isentropic efficiency. The overall isentropic efficiency is the ratio between theoretical power of a isentropic compression process and the actual electric power. The overall and volumetric efficiency were determined fitting the Eqs. (10) and (11) to the performance map provided by the compressor manufacturers as proposed by Minetto (2011).

$\eta_{v}=\mathrm{a}_{1} \mathrm{r}+\mathrm{a}_{0}$

$\eta_{g}=\mathrm{a}_{4} \mathrm{r}^{2}+\mathrm{a}_{3} \mathrm{r}+\mathrm{a}_{2}$

where $a_{0}$ to $a_{4}$ are the regression coefficients and $r$ is the pressure ratio $\left(P_{2} / P_{1}\right)$.

\subsection{Immersed condenser}

To operate with immersed condenser the hot water tank is filled with cold water before the DX-SAHP start. Assuming that the water at the tank is non stratified the energy balance in the hot water tank is given by:

$\dot{\mathrm{Q}}_{\mathrm{t}}=\rho_{w} V_{w} C_{w} \frac{\partial T_{w}}{\partial t}$

where $t$ is time.

The balance of energy is applied divided in three parts: gas flow region, condensation region and liquid flow region. The heat transfer in the three regions is given by:

$\dot{\mathrm{Q}}_{i c}=\dot{\mathrm{m}}_{r e} \Delta \mathrm{i}=\mathrm{UA}\left(\overline{\mathrm{T}}_{r e}-T_{w}\right)$

where $\Delta i$ represents, in the gas flow region, the difference of the en- 
thalphy at condenser inlet and the saturated vapor enthalpy; in the condensation region, the enthalpy of vaporization; and in the liquid flow region, the difference of saturated liquid enthalpy and the enthalphy at condenser outlet. The UA value is evaluated as follow:

$\mathrm{UA}=\left(\frac{1}{H_{i} A_{i}}+\frac{\ln \left(D_{o} / D_{i}\right)}{2 \pi k l_{c d}}+\frac{1}{H_{o} A_{o}}\right)^{-1}$

where $l_{c d}$ is the condenser length.

The inner convective coefficient $\left(H_{i}\right)$ is obtained from the correlations proposed by Gnielinski (1976) and Shah Shah (2016) in, respectively, single and two phase flow. To outer convective coefficient $\left(H_{0}\right)$ is adopted the correlation for free convection in a horizontal cylinder presented by Neils and Klein (2009).

In order to consider the heat loss in the hot water tank, Kong et al. (2017) propose a heat leakage coefficient of $95 \%$ which is defined as follow:

$\zeta=\frac{\dot{\mathrm{Q}}_{\mathrm{t}}}{\dot{\mathrm{Q}}_{i c}}$

\subsection{Coaxial condenser}

During the operation with coaxial condenser the hot water tank is filling with hot water, so the energy balance in the hot water tank is given by:

$\dot{\mathrm{Q}}_{\mathrm{t}}=\dot{\mathrm{m}}_{\mathrm{w}} C_{w}\left(T_{w}-\mathrm{T}_{w i n}\right)$

where $\dot{\mathrm{m}}_{\mathrm{w}}$ is the water mass flow rate, $T_{\text {win }}$ is the water inlet temperature and $T_{w}$ is the water temperature at the water tank.

The balance of energy at the coaxial condenser is given by:

$\dot{\mathrm{Q}}_{c c}=\dot{\mathrm{m}}_{r e}\left(\mathrm{i}_{2}-\mathrm{i}_{3}\right)=\dot{\mathrm{m}}_{\mathrm{w}} C_{w}\left(\mathrm{~T}_{\text {wout }}-\mathrm{T}_{\text {win }}\right)$

where $T_{\text {wout }}$ is the water outlet temperature.

The heat transfer at coaxial condenser is modeled using the effectiveness-NTU method. The effectiveness is evaluated as follow:

$\xi=\frac{\dot{\mathrm{Q}}_{c d}}{\dot{\mathrm{C}}_{\min }\left(\mathrm{T}_{2}-\mathrm{T}_{\text {win }}\right)}$

$\xi=\frac{1-\exp [-N T U(1-\mathrm{R})]}{1-\exp [-N T U(1-\mathrm{R})] \mathrm{R}}$

where $\dot{C}$ is the product of mass flow rate and heat capacity, $\dot{\mathrm{C}}_{\min }$ is the smaller heat capacity rate between the refrigerant and the water. $R$ is the heat capacity ratio given by:

$\mathrm{R}=\frac{\dot{\mathrm{C}}_{\min }}{\dot{\mathrm{C}}_{\max }}$

and the number of transfer units is defined as:

$N T U=\frac{\mathrm{UA}}{\dot{\mathrm{C}}_{\min }}$

where UA is evaluated by the Eq. (14) and $\dot{\mathrm{C}}_{\max }$ is the largest heat capacity rate between the refrigerant and the water. For water flowing at annular region, the convective coefficient was calculated by correlations proposed by Rohsenow et al. (1998) considering a constant heat flux, for refrigerant the Gnielinski (1976) and Shah (2016) correlations were used.

\subsection{Expansion device}

The expansion devices required for a DX-SAHP are the electronic valve or a thermostatic valve because of large variations in solar radiation. The expansion valve is used to control the superheat at evaporator outlet, it is modeled as isenthalpic expansion device and the mass flow rate can be calculated as follow:

$\dot{\mathrm{m}}_{r e}=\mathrm{c}_{e d} \mathrm{~A}_{e d} \sqrt{2 \rho_{3}\left(\mathrm{P}_{3}-\mathrm{P}_{4}\right)}$

where $A_{e d}$ is the area of the orifice valve, $P$ is pressure, $\rho$ is density, the subscripts 3 and 4 represent the inlet and outlet valve, $c_{e d}$ is the flow coefficient or flow factor calculated by Eq. (23) proposed by Kong et al. (2011).

$\mathrm{c}_{e d}=0.02005 \sqrt{\rho_{3}}+\frac{0.634}{\rho_{4}}$

More details about the modeling procedure and the correlations used are presented in Duarte (2018).

\subsection{Energetic and environmental metrics}

Some authors (Davies and Caretta, 2004; Tsamos et al., 2017; Xu et al., 2013; Makhnatch and Khodabandeh, 2014a) use the Total Equivalent Warming Impact (TEWI) to analysis the environment impact of the refrigerant. Makhnatch and Khodabandeh (2014a) used the formula in Eq. (24) for TEWI.

$T E W I=G W P \cdot \mathrm{L} \cdot \mathrm{N}+\mathrm{E} \cdot \beta \cdot \mathrm{N}$

In this equation GWP is the value of Global Warming Potential which values for the refrigerants analyzed in this work are shown in Table $1, L$ is the annual refrigerant leakage rate (typically, $3 \%$ of charge (Makhnatch and Khodabandeh, 2014a)), $N$ is the system lifetime (typically, 15 years (Makhnatch and Khodabandeh, 2014a)), $E$ is the annual energy consumption and $\beta$ is the emission factor for producing electricity. In the Eq. (24), the first term represents the direct emissions and the second one represents the indirect emissions.

The charge of refrigerant is evaluated by the Eq. (25) for single phase flow and by the Eq. (26) for two phase flow. The void fraction $(\alpha)$ is calculated by Hughmark (1965).

$\mathrm{m}_{r e}=\int \rho_{r e} d V$

$\mathrm{m}_{r e}=\int\left[\alpha \rho_{V}+(1-\alpha) \rho_{L}\right] d V$

where the subscripts $l$ and $v$ refer to the liquid and vapor, respectively.

To characterize the heat pump performance just from the point of view of the refrigerant, and considering only the work of a isentropic compression process $\left(W_{s}\right)$, the COP of the thermodynamics cycle is given by:

$C O P_{\mathrm{s}}=\frac{\rho_{w} C_{w} V_{w}\left(\mathrm{~T}_{w f}-\mathrm{T}_{w i}\right)}{W_{s}}$

\section{Discussion of results}

In this section, the results generated by the mathematical model are discussed. First, the validation of the model is presented and in sequence the model is used with focus on the main objective of this work: the selection of the best refrigerant for the DX-SAHP. 


\subsection{Modelling validation}

The model validation was performed using the results from $20 \mathrm{ex}$ periments of a R134a DX-SAHP published by Diniz (2017), as presented in Section 3. In the simulations made for validation, the superheat was assumed constant at $7.4^{\circ} \mathrm{C}$. This value is the average value obtained from experimental results. The values of solar radiation, temperatures, atmospheric pressure, relative humidity and wind speed were kept constant at the mean value obtained from each experimental tests listed in Tables 2 and 3 . The value of solar absorptivity was assumed the same of measured emissivity (0.95). For the immersed condenser the charge of refrigerant was assumed constant $(433 \mathrm{~g}$ ) and for the coaxial condenser the subcooling was considered constant at $6.5^{\circ} \mathrm{C}$. These assumptions were based on the experimental observation of the subcooling. In addition, the input variables used in the model are only the geometric parameters of the DX-SAHP, values of the initial and final temperature of the tank, and the volume of water in the tank.

The comparison between experimental and theoretical COPs is shown in Fig. 2 for both condensers (Immersed and Coaxial). The mean difference between the COPs is $1.6 \%$, which is lower than the uncertainty of the experimental COP (5\%). Considering only the results from immersed condenser the mean difference are $1.7 \%$ while, for the results from coaxial condenser, this difference is $1.6 \%$. Considering the method for evaluation of uncertainty in numerical modelling described by ASME (2009), the uncertainty of COP calculated by the model is at least $1.6 \%$.

In Fig. 2, points with COP inside the circle was obtained with the heat pump operating inside the laboratory (without solar radiation), in this case it works as an air source heat pump (ASHP). In the other points, the equipment was under solar radiation and an increase of the COP took place. For these points, the heat pump operates as a solar assisted heat pump, and the experimental COP is up to $26.5 \%$ higher than the COP for air source heat pump mode.

\subsection{Thermal and environmental performance}

In the following results, the simulations were done considering the geometrical parameters described in Section 3 and the final water temperature of $65{ }^{\circ} \mathrm{C}$, which value was chosen based in guideline of ASHRAE (2000) to minimize the risk of formation Legionellosis bacteria in the water. The superheat was $15{ }^{\circ} \mathrm{C}$, and initial/inlet water temperature were $25^{\circ} \mathrm{C}$. The emission factor for producing electricity $(\beta)$ is fixed in $130 \mathrm{~g} / \mathrm{kWh}$. Two strategies were adopted for the simulations.

In this study, R744 operates with transcritical cycle and a correlation for the high pressure in order to maximize the COP is required. As

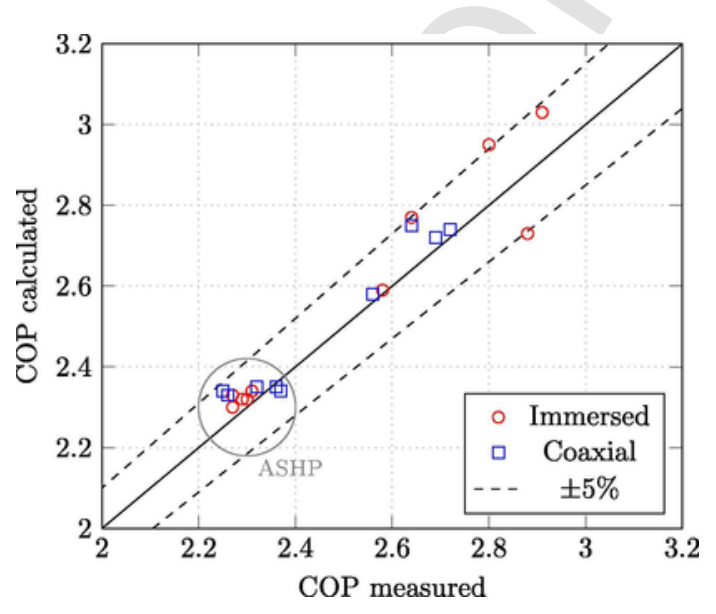

Fig. 2. Comparison of experimental and predicted COP. there are no correlations for DX-SAHP operating with $\mathrm{CO}_{2}$, seven correlations for different systems available in the literature (Liao et al., 2000; Sarkar et al., 2004; Aprea and Maiorino, 2009; Kim et al., 2009; Qi et al., 2013; Wang et al., 2013; Yang et al., 2015) were tested and the best results were found by the correlation presented by Aprea and Maiorino (2009). The same methodology used to modeling the coaxial condenser was used by Islam et al. (2012) to modeling a coaxial gas cooler. The performance of R744 using an immersed gas cooler was not analyzed because of the gas cooler pressure required to heat water at the temperatures recommended by ASHRAE (2000) is higher than the maximum pressure of the compressors available in the market. Additionally, none study using a R744 immersed gas cooler was found in the literature.

To use a realistic value of the overall and volumetric efficiencies the Eqs. (10) and (11) were fitted to the performance data of commercial compressors. These commercial compressors were chosen, for each the selected refrigerants, considering the refrigeration capacity of R134a reference compressor at $20{ }^{\circ} \mathrm{C}$. The selected compressors are listed in Table 4. The volumetric and overall efficiencies equations fitted to manufacturers performance data for each compressor are shown in the Figs. 3 and 4.

The performance data of the selected compressors were obtained for evaporating temperatures from $-15^{\circ} \mathrm{C}$ to $15^{\circ} \mathrm{C}$ and condensing temperatures from $35^{\circ} \mathrm{C}$ to $65^{\circ} \mathrm{C}$, or from 80 bar to $100 \mathrm{Bar}$ for $\mathrm{CO}_{2}$. The performance data provided by the manufacturers have uncertainty from 5 to 7\%. The maximum global efficiency $\left(\eta_{g}\right)$ for refrigerants R290, R600a and R744 is approximately the same. The refrigerant R1234yf has lower efficiency, which is compensate by its more ecological character. The values of overall isentropic efficiency showed in Fig. 4 are typical for small hermetic compressor with input power lower than $250 \mathrm{~W}$.

\subsubsection{Immersed condenser}

The charge of refrigerant, for operation with immersed condenser, was calculated with the heat pump operating without solar radiation, in the ambient temperature of $0{ }^{\circ} \mathrm{C}$, and subcooling of $5{ }^{\circ} \mathrm{C}$. The refrig-

Table 4

Selected compressors.

\begin{tabular}{llll}
\hline Ref. & Model & Manufacturer & $V_{c}\left(\mathrm{~cm}^{3}\right)$ \\
\hline R1234yf & AE4430HFZ & Tecumseh & 8.02 \\
R134a & FF85HBK & Embraco & 7.95 \\
R290 & NEK2121U & Embraco & 6.2 \\
R600a & NEK6170Y & Embraco & 14.28 \\
R744 & SRADB & Sanden & 1.75 \\
\hline
\end{tabular}

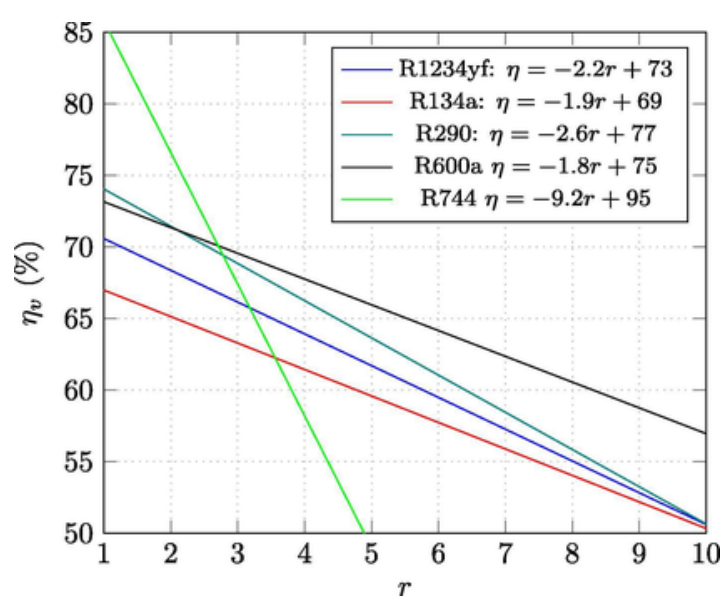

Fig. 3. Volumetric efficiency function of pressure ratio. 


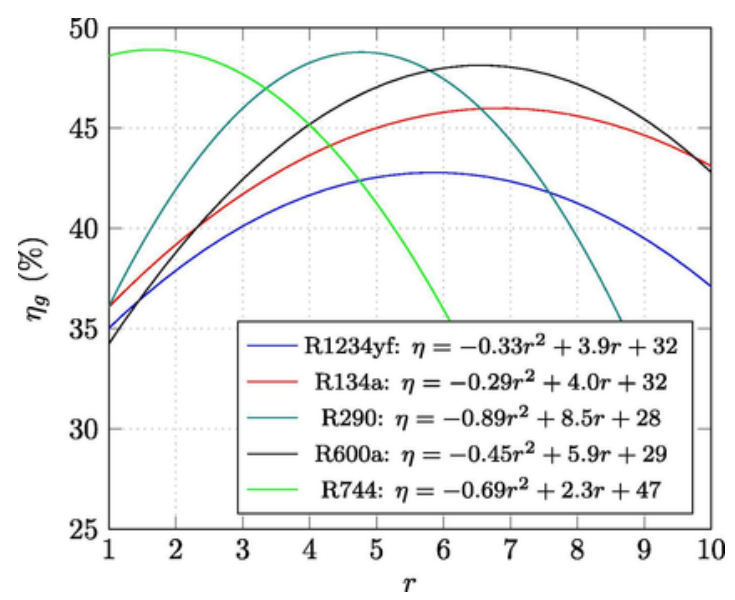

Fig. 4. Overall efficiency function of pressure ratio.

erants charges are $408 \mathrm{~g}, 433 \mathrm{~g}, 200 \mathrm{~g}$ and $230 \mathrm{~g}$ for R1234yf, R134a, R290 and R600a, respectively.

Fig. 5 shows the solar radiation effect on the COP the DX-SAHP equipped with an immersed condenser for all refrigerants (fixed values for the wind speed and environment temperature). There is an expressive improvement of the COP. For example, R290-COP increases of 44\% when the solar radiation grows from 0 to $700 \mathrm{~W} / \mathrm{m}^{2}$. This behavior of the COP is similar to those described by Kong et al. (2011) for R22 and by Kong et al. (2017) for R410A. R134a has the best COP without solar radiation and $\mathrm{R} 290$ has the best COP for solar radiation greater than 50 $\mathrm{W} / \mathrm{m}^{2}$. The COP of R290 is on average $1.2 \%$ better than R134a, $1.9 \%$ better than R600a and 11.3\% better than R1234yf.

Comparing the results of COP without solar radiation from Figs. 2 and 5 the COP decreased approximately $22 \%$ when the final water temperature increases from $45^{\circ} \mathrm{C}$ to $65^{\circ} \mathrm{C}$. A similar analysis is performed considering an isentropic compression process as shows Fig. 6 . In this analysis, the R134a has the best COP followed by R1234yf, as expected since this heat pump was designed originally for R134a. This also shows the potential for improvement of the compressor for R1234yf.

Fig. 7 shows the variation of the COP with the wind speed for all refrigerants (fixed values for solar radiation and ambient temperature). The maximum performance improvement is around $1 \%$ for any refrigerant. The variation of COP with the environment temperature is shown in the Fig. 8. For the R134a, the COP increases $8 \%$ when its temperature changes from $10{ }^{\circ} \mathrm{C}$ to $35{ }^{\circ} \mathrm{C}$, while for the other refrigerants the increase is $9 \%$. These increases of the COP with ambient tem-

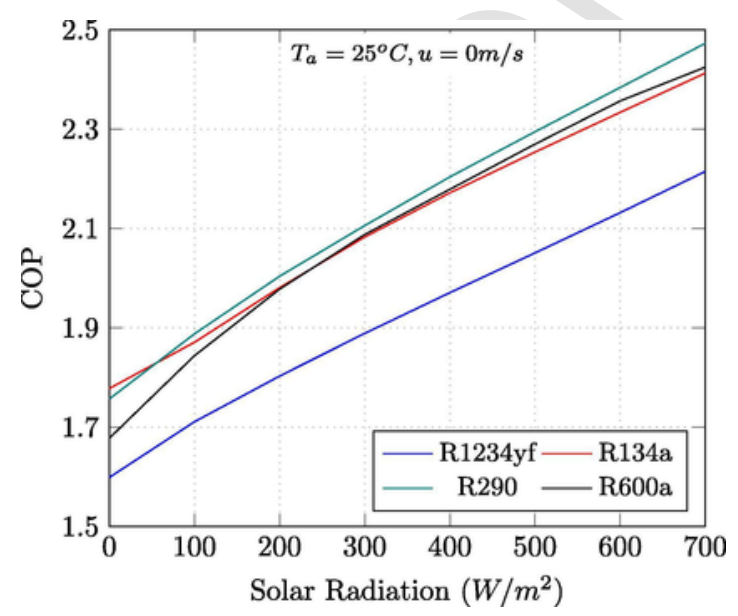

Fig. 5. The variation of COP function of solar radiation for immersed condenser.

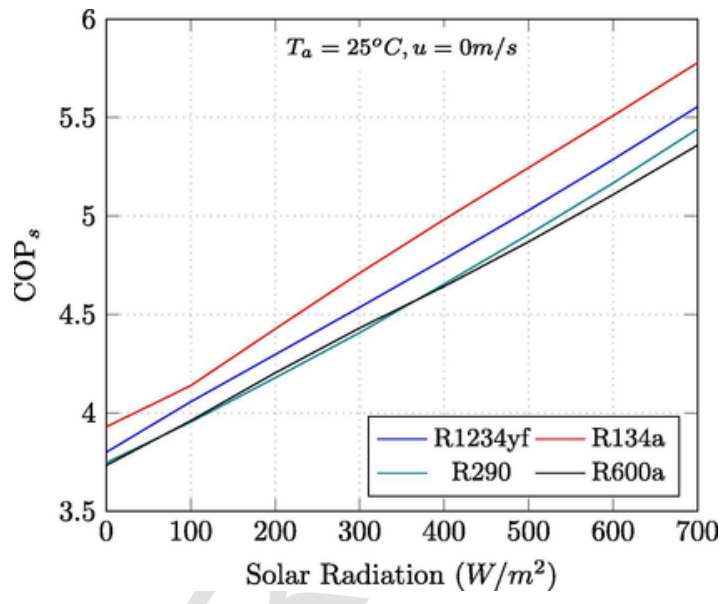

Fig. 6. The variation of $\mathrm{COP}_{s}$ function of solar radiation for immersed condenser.

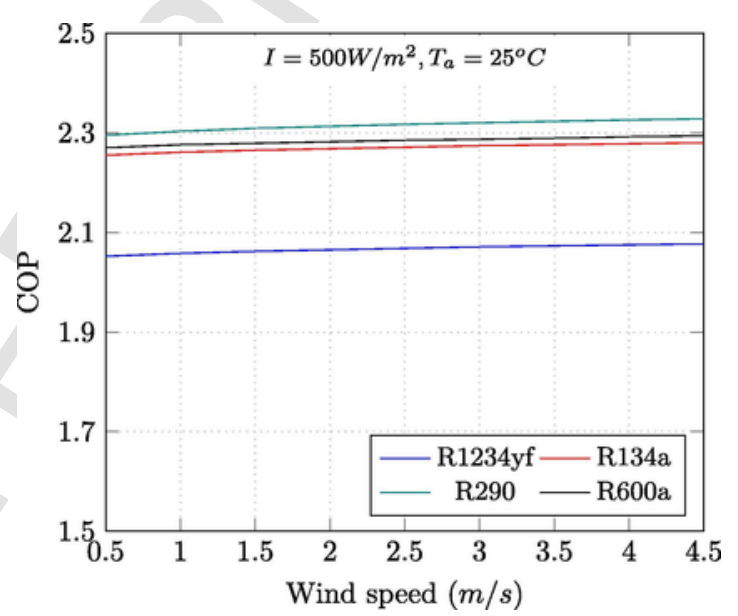

Fig. 7. The variation of COP function of wind speed for immersed condenser.

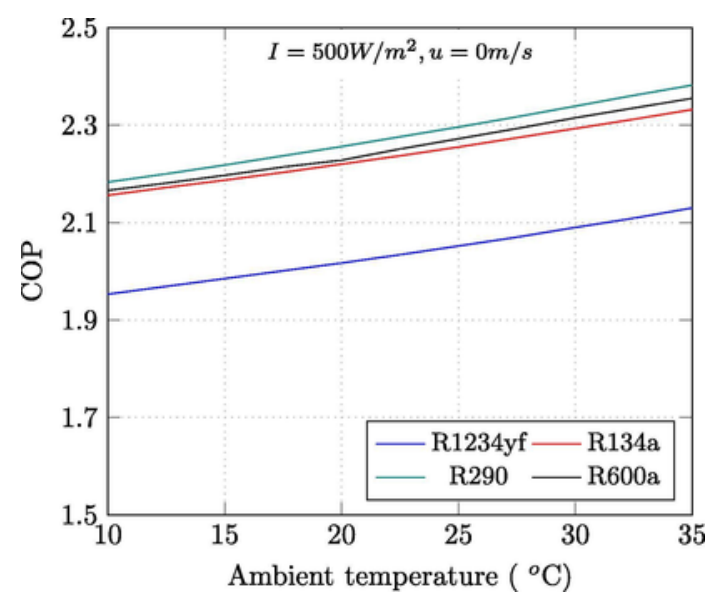

Fig. 8. The variation of COP function of ambient temperature for immersed condenser.

perature and wind velocity in a DX-SAHP are also observed by Kong et al. (2011)

The TEWI for different solar radiation is shown in Fig. 9. The refrigerant with lowest TEWI is the R290. To compare the environmental metrics, the TEWI of an electric heater with $97 \%$ of efficiency in the same conditions is $6.52 \mathrm{t} \mathrm{CO}_{2}$-eq. For the $\mathrm{R} 134 \mathrm{a}$, its contribution with direct emissions represents $7 \%$ to $9.2 \%$ of the TEWI value and for the other refrigerants the direct emissions are lower then $0.1 \%$. Therefore, 


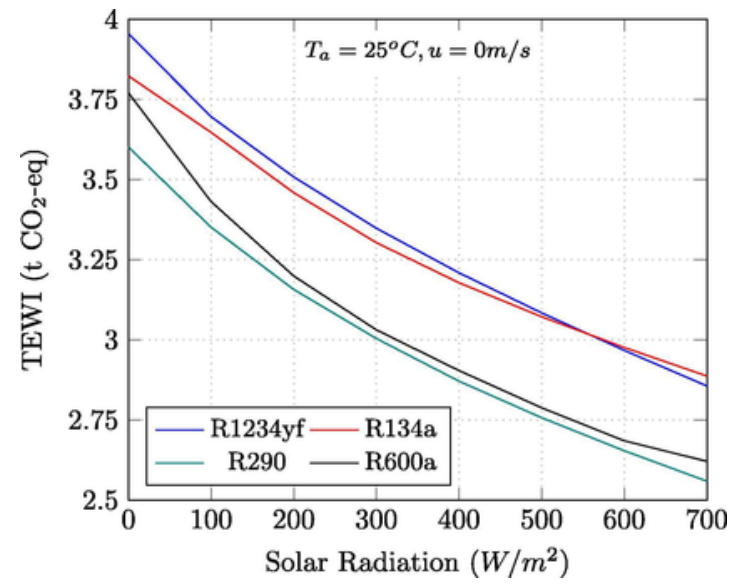

Fig. 9. The variation of TEWI function of solar radiation for immersed condenser.

among the refrigerants with GWP lower than 150, the one with higher COP will have lowest environmental impact.

\subsubsection{Coaxial condenser}

The simulations with this type of condenser was done considering a subcooling of $6.5^{\circ} \mathrm{C}$. The charge required for this setup is $300 \mathrm{~g}, 276 \mathrm{~g}$, $110 \mathrm{~g}, 137 \mathrm{~g}$ and $400 \mathrm{~g}$ for the refrigerants R134a, R1234yf, R600a, R290 and R744, respectivally. Because of lower diameter of this heat exchanger, the maximum charge required by R134a, R1234yf and R290 is around $30 \%$ lower than the one required with immersed condenser and of $52 \%$ lower for the R600a.

The COP of the heat pump with coaxial condenser in function of solar radiation is presented in Fig. 10. Considering the refrigerant $\mathrm{R} 1234 \mathrm{yf}$, the COP if the solar radiation is $700 \mathrm{~W} / \mathrm{m}^{2}$ is $46 \%$ higher than the COP of ASHP (without solar radiation). The average COP of the $\mathrm{R} 290$ is $0.1 \%, 6.3 \%, 20.5 \%$ and $21.5 \%$ is better than the COP of R134a, R600a, R744 and R1234yf, respectively. The COP of R290 is in average $1.2 \%$ better than R134a, 1.9\% better than R600a and $11.3 \%$ better than R1234yf. Comparing the results of COP without solar radiation from Figs. 2 and 10 the COP decreased approximately $21 \%$ when the final water temperature increased from $45^{\circ} \mathrm{C}$ to $65^{\circ} \mathrm{C}$. Again, as presented in Fig. 11, the analysis considering an isentropic compression process shows that R134a has the best COP without solar radiation, R290 has the best COP for high solar radiation and R134a has the best $\mathrm{COP}_{s}$.

Figs. 12 and 13 shows the increase of the COP with the wind speed and ambient temperature. The COP of DX-SAHP increases from $1.9 \%$ to

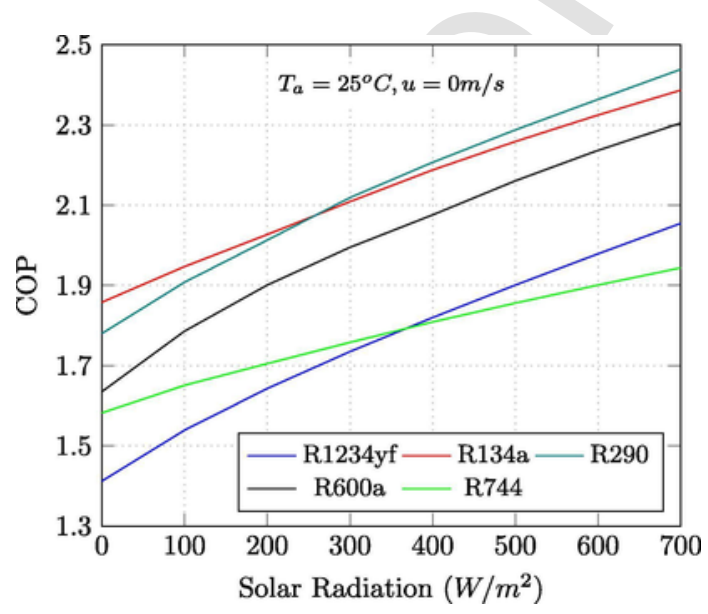

Fig. 10. The variation of COP function of solar radiation for coaxial condenser.

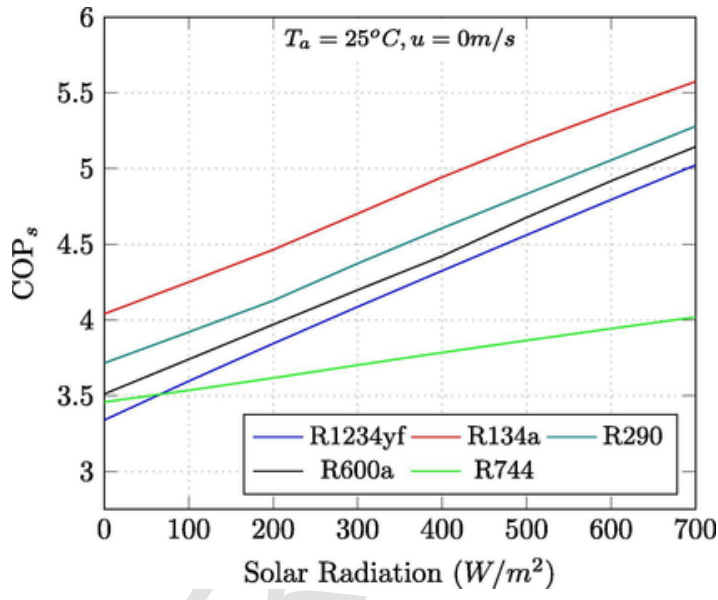

Fig. 11. The variation of $\mathrm{COP}_{s}$ function of solar radiation for coaxial condenser.

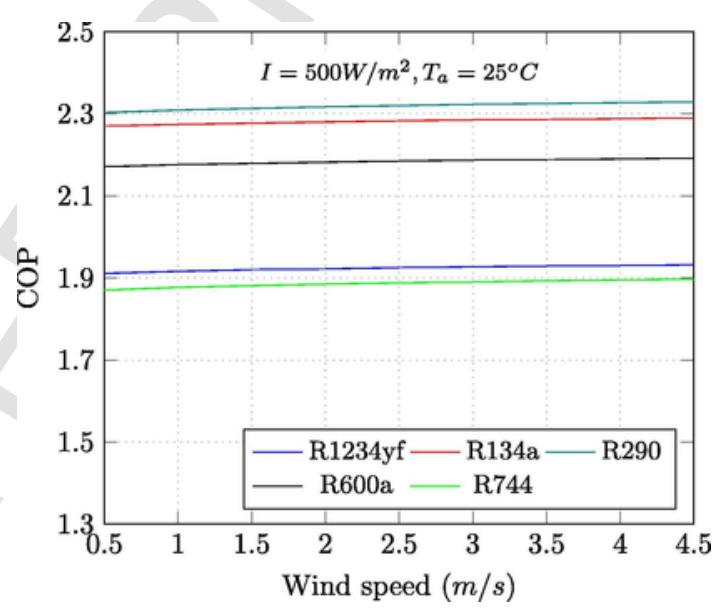

Fig. 12. The variation of COP function of wind speed for coaxial condenser.

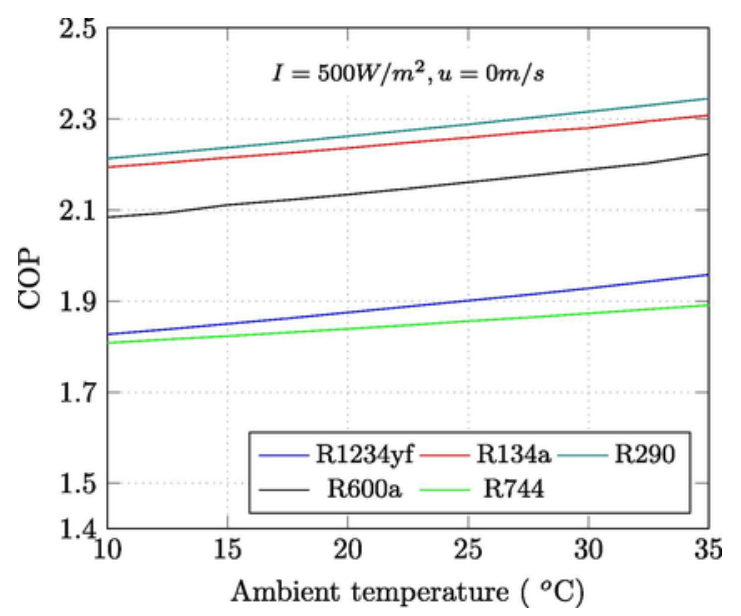

Fig. 13. The variation of COP function of ambient temperature for coaxial condenser.

$3 \%$ if the wind speed increases from $0 \mathrm{~m} / \mathrm{s}$ to $4.5 \mathrm{~m} / \mathrm{s}$, and from $4.5 \%$ to $7 \%$ if the ambient temperature changes from $10{ }^{\circ} \mathrm{C}$ to $35^{\circ} \mathrm{C}$.

The refrigerant with the lowest TEWI for a coaxial condenser is also the R290 as shown in Fig. 14. In this case, the contribution of direct emissions in the TEWI is $5 \%$ to $6.5 \%$ for R134a and is lower then $0.1 \%$ for the other refrigerants. For higher solar radiation, the worst TEWI is that one from R744, and for lower solar radiations is that one from R1234yf. 


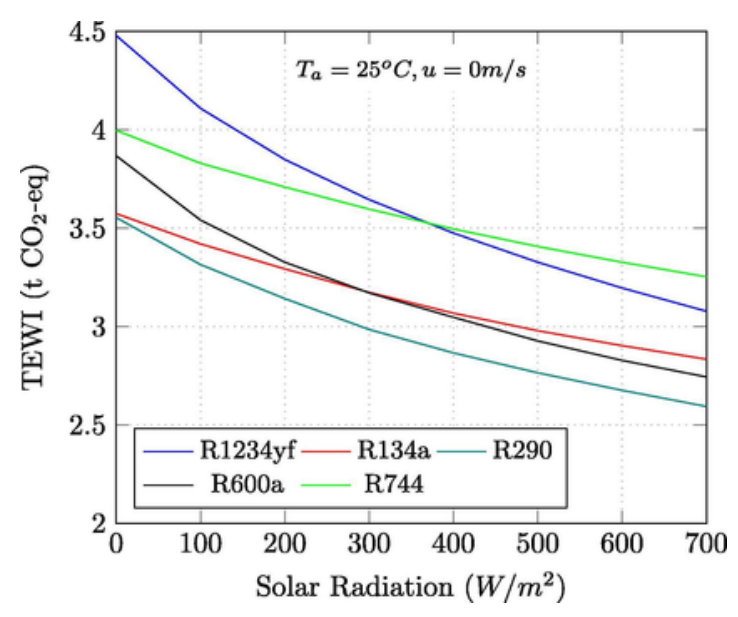

Fig. 14. The variation of TEWI function of solar radiation for coaxial condenser.

The COP of R134a and R290 with the immersed condenser is on average the same with the coaxial condenser, but for R1234yf and R600a the COP is $9.3 \%$ and $4.3 \%$ better with the immersed condenser. The TEWI for R1234yf, R134a and R600a are 8.5\%, 4.3\% and 4.2\% lower for the immersed condenser than for the coaxial condenser, respectively. The average TEWI for R290 are the same with both condensers.

It is also important to highlight that the best COP of the R290 compared with the R1234yf was found in the results presented by Makhnatch and Khodabandeh (2014b), Ghoubali et al. (2014) and Botticella and Viscito (2015) for different systems.

\subsection{Parametric analysis}

It is interesting to change some fixed parameters in the previous results, and to check the variance of the results. For this parametric analysis the model with coaxial condenser was used because of the lower computational effort and the similar results between the two types of condensers. The environmental condition is kept constant with a solar radiation of $500 \mathrm{~W} / \mathrm{m}^{2}$, an ambient temperature of $25{ }^{\circ} \mathrm{C}$, and without wind. The first important parameter is the $\mathrm{CO}_{2}$ emission factor for producing electricity since each country or region keep different values. The variation of TEWI for different emission factor is shown in Fig. 15. In countries with lower emission factors, around $20 \mathrm{~g} / \mathrm{kWh}$, the TEWI of $\mathrm{R} 290$ is $0.43 \mathrm{t} \mathrm{CO}_{2}$-eq. The worst TEWI is of the $\mathrm{R} 134 \mathrm{a}\left(0.617 \mathrm{t} \mathrm{CO}_{2}\right.$-eq). In countries with higher emission factor the refrigerant with the best COP has the best TEWI.

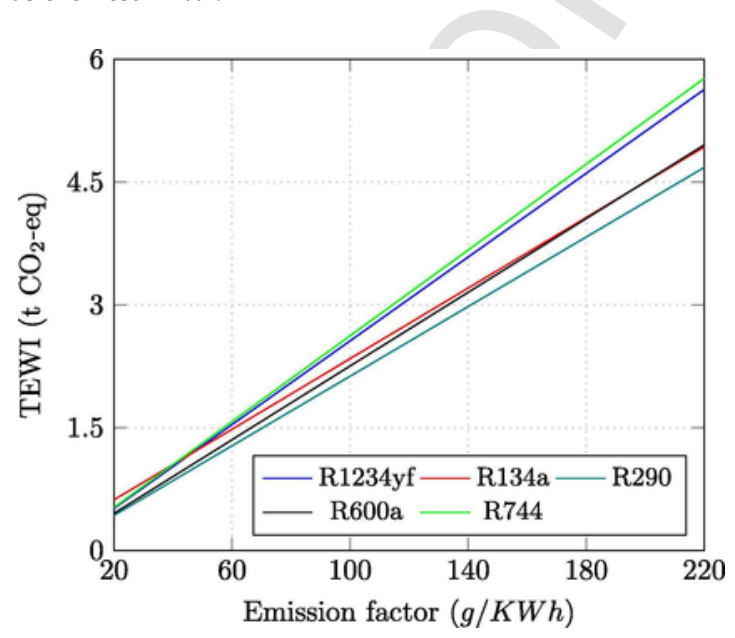

Fig. 15. The variation of TEWI function of emission factor.
The length of the condenser or gas cooler, in case of the for R744, is another important parameter. It is known that the heat transfer coefficient for a gas is lower than the heat transfer coefficient in condensation region for the same mass flux rate. Figs. 16 and 17 show the variation of COP and TEWI in function of the gas cooler/condenser length. For the $\mathrm{CO}_{2}$, the sudden change in the inclination of COP and TEWI curves happens in the transition between transcritical and sub-critical cycle. For a length higher than $18.5 \mathrm{~m}$, the COP increase and TEWI decrease rates are very low for all refrigerants. Besides of that, for this length, the COP of the R290 is 3\% higher than the COP of the R744.

Among the refrigerants compared, the results show that R290 has better COP than others refrigerants for solar radiation between $300 \mathrm{~W} /$ $\mathrm{m}^{2}$ and $700 \mathrm{~W} / \mathrm{m}^{2}$, as well as for ambient temperature between $10{ }^{\circ} \mathrm{C}$ and $35{ }^{\circ} \mathrm{C}$. On the other hand, for solar radiation less than $50 \mathrm{~W} / \mathrm{m}^{2}$, the R134a has the best COP. The TEWI analysis indicates that the indirect emission is the most important effect, so this parameter results almost followed the COP outcome. Considering the uncertainty of the mathematical model, the R290 and R600a have the same performance if an immersed condenser is used. In addition, the R744 performance is slightly lower than the R290 performance, but this refrigerant requires a large heat exchanger.

In order to perform additional simulations with the R290, in the next section, it will be presented the variation of the COP of the R290 DX-SAHP for a wide range of solar radiation, ambient temperature and wind speed. These simulations were performed with R290 because the results indicated R290 as the best option for replacement of R134a.

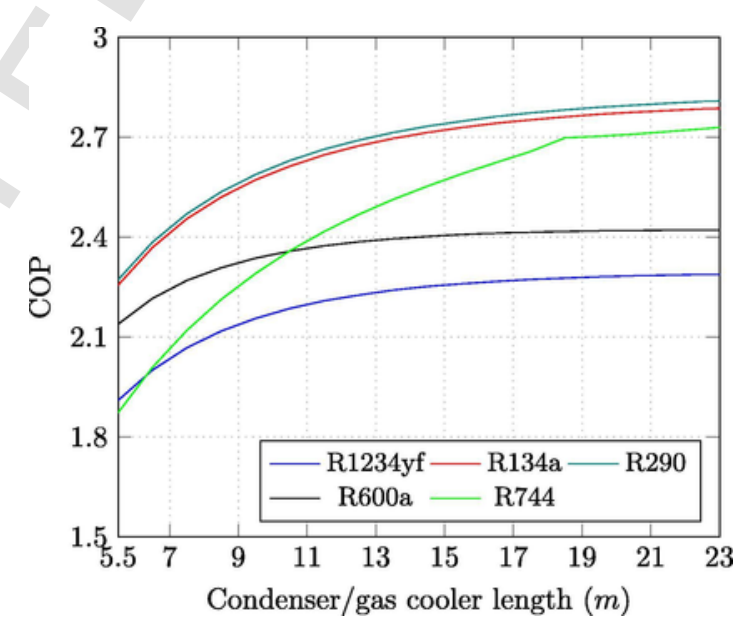

Fig. 16. The variation of COP function of condenser/gas cooler length.

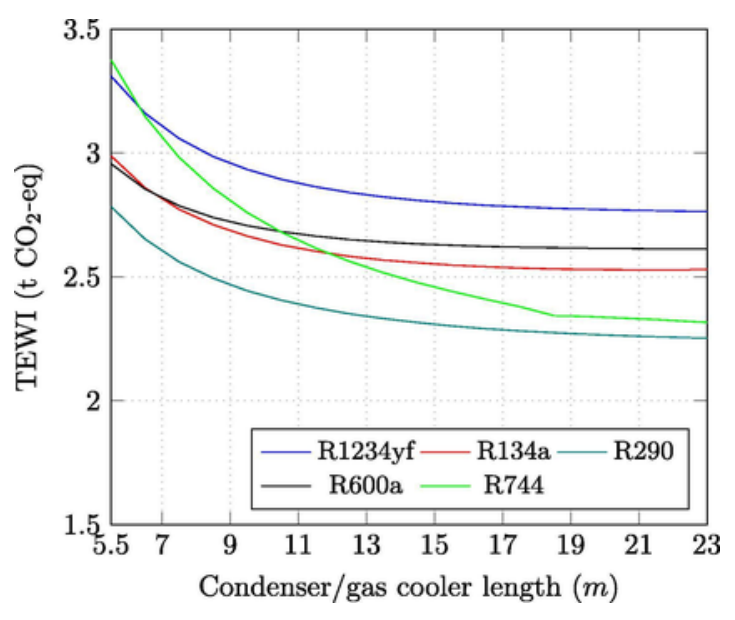

Fig. 17. The variation of TEWI function of condenser/gas cooler length. 


\subsection{Performance of R290 DX-SAHP}

Figs. 18 and 19 shown the influence of wind speed in COP for different solar radiation for immersed and coaxial condenser, respectively. In both cases, the influence of wind speed for solar radiation of $700 \mathrm{~W} / \mathrm{m}^{2}$ is lower than $0.5 \%$. These results are similar of those found by Paradeshi et al. (2016) for a DX-SAHP using R22 and an air cooled condenser. Furthermore, for the solar radiation of $100 \mathrm{~W} / \mathrm{m}^{2}$, the COP increases around $4.5 \%$, when the wind speed changes from $0.5 \mathrm{~m} / \mathrm{s}$ to $4.5 \mathrm{~m} / \mathrm{s}$. This behavior occurs for both condensers. It seems that the effect of the wind speed in a R290 DX-SAHP is more relevant in low solar radiations.

Figs. 20 and 21 show the influence of ambient temperature in COP for different solar radiation for each type of condenser. The shape of these curves are similar of those presented by Kuang et al. (2003) and Paradeshi et al. (2016) for a R22 DX-SAHP. In Fig. 20 when the ambient temperature changes from $0{ }^{\circ} \mathrm{C}$ to $35^{\circ} \mathrm{C}$, the COP increases of $37 \%, 19 \%, 14 \%$ and $12 \%$ for the solar radiation of $100 \mathrm{~W} / \mathrm{m}^{2}, 300 \mathrm{~W} /$ $\mathrm{m}^{2}, 500 \mathrm{~W} / \mathrm{m}^{2}$ and $700 \mathrm{~W} / \mathrm{m}^{2}$, respectively. Furthermore, in Fig. 21 when the ambient temperature changes from $0{ }^{\circ} \mathrm{C}$ to $35^{\circ} \mathrm{C}$, the COP increases of $20 \%, 14 \%, 10 \%$ and $9 \%$ for the solar radiation of $100 \mathrm{~W} /$ $\mathrm{m}^{2}, 300 \mathrm{~W} / \mathrm{m}^{2}, 500 \mathrm{~W} / \mathrm{m}^{2}$ and $700 \mathrm{~W} / \mathrm{m}^{2}$, respectively. It shows that the R290 DX-SAHP is more influenced by the ambient temperature in low

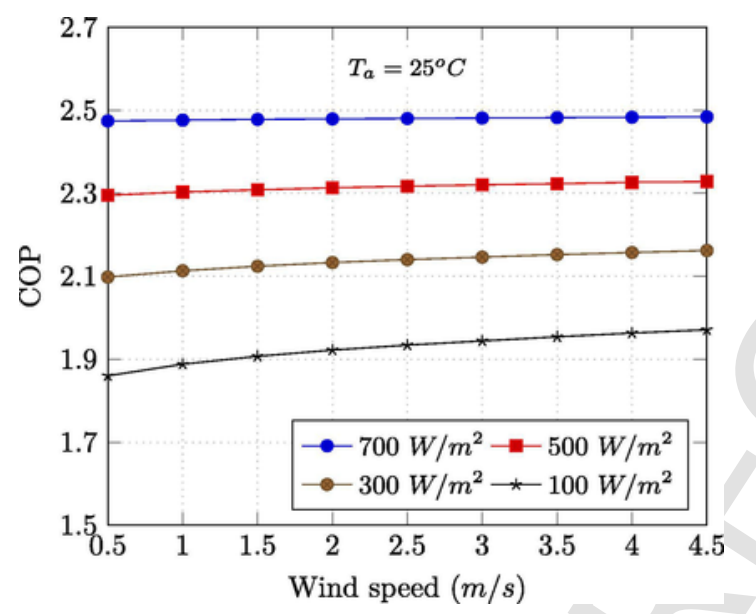

Fig. 18. The variation of COP function of wind speed for immersed condenser considering different solar radiation.

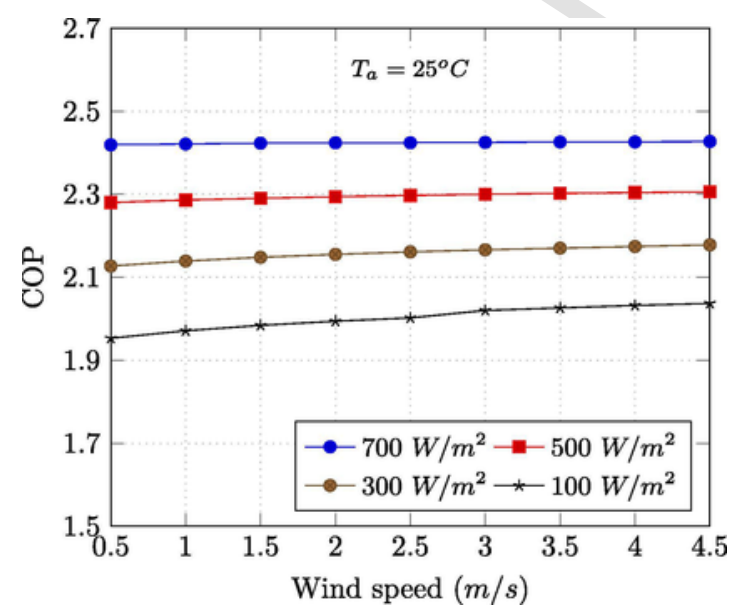

Fig. 19. The variation of COP function of wind speed for coaxial condenser considering different solar radiation.

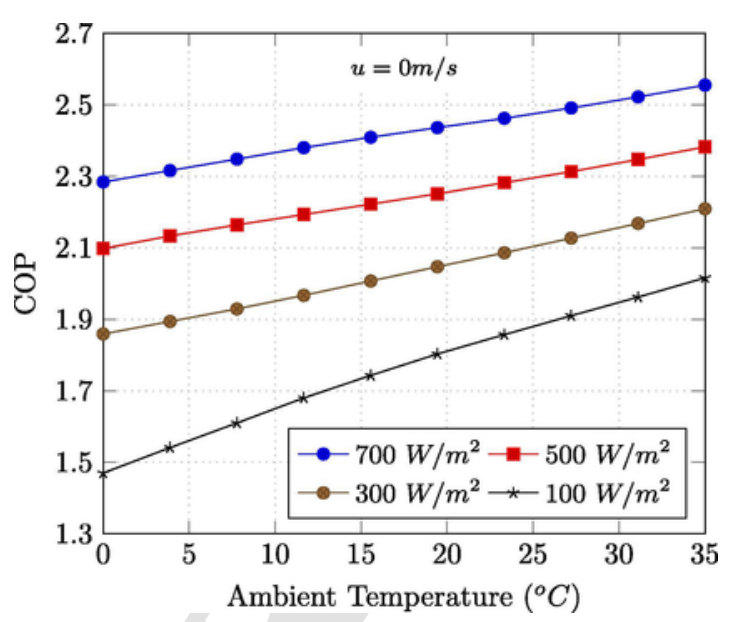

Fig. 20. The variation of COP function of ambient temperature for immersed condenser considering different solar radiation.

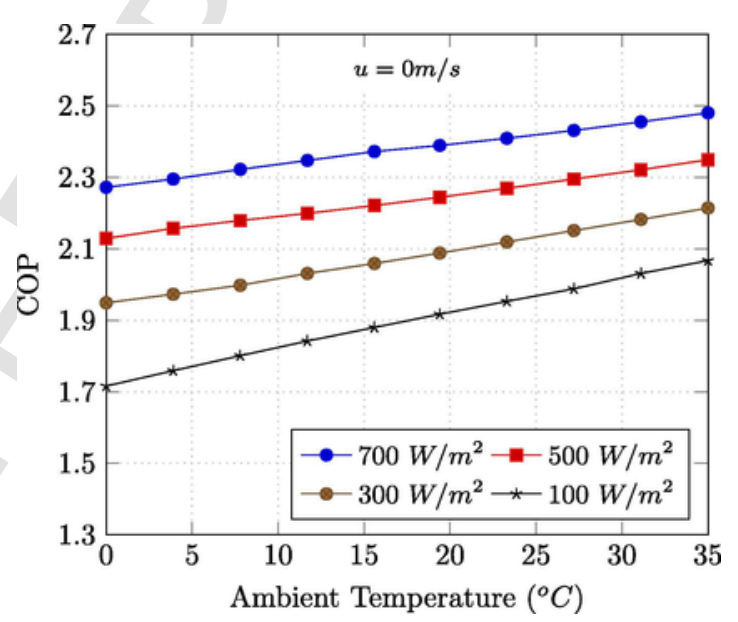

Fig. 21. The variation of COP function of ambient temperature for coaxial condenser considering different solar radiation.

solar radiations. In addition, the variations of COP due to the ambient temperature are greater when the immersed condenser is used.

\section{Conclusions}

A comparison of refrigerants for a direct expansion solar assisted heat pump has been carried out in terms of thermal performance and environmental impact. The thermal performance parameter used in this work was the COP of a DX-SAHP, and the environmental impact parameter was the TEWI. A immersed and a coaxial condenser/ gas cooler was considered in the analysis. The refrigerants selected were the R134a, R290, R600a, R744 and R1234yf. The model used was validated in terms of COP with the mean differences between the COP experimental and COP theoretical of $1.6 \%$. The analyses is performed with the solar radiation between $0 \mathrm{~W} / \mathrm{m}^{2}$ and $700 \mathrm{~W} / \mathrm{m}^{2}$, the ambient temperature between $10{ }^{\circ} \mathrm{C}$ and $35{ }^{\circ} \mathrm{C}$ and the wind speed between $0.5 \mathrm{~m} /$ $\mathrm{s}$ and $4.5 \mathrm{~m} / \mathrm{s}$. Among the refrigerants compared, the results show that R290 has better COP than others refrigerants for solar radiation between $300 \mathrm{~W} / \mathrm{m}^{2}$ and $700 \mathrm{~W} / \mathrm{m}^{2}$, as well as, for ambient temperature between $10{ }^{\circ} \mathrm{C}$ and $35{ }^{\circ} \mathrm{C}$. On the other hand, for solar radiation less than $50 \mathrm{~W} / \mathrm{m}^{2}$, the R134a has better COP than other refrigerants. The TEWI analysis is very important. In general, it has been found that the lower the TEWI value, the higher the COP value of a refrigerant. Additionally, on the length of the high pressure heat exchanger, it was observed that this value significantly interferes in the COP and TEWI of 
the heat pump. For a length higher than 18.5 meters for the gas cooler/ condenser, the COP of R290 is 3\% higher than the COP of R744. Finally, for lower solar radiation the COP of a R290 DX-SAHP is more influenced by ambient temperature and wind speed than for higher solar radiation.

\section{Acknowledgments}

This work was supported by Foundation for Research Support of the State of Minas Gerais (FAPEMIG) through the project AUC-00032-16 and by Coordination for the Improvement of Higher Education Personnel (CAPES) through the program PNPD/CAPES. The authors appreciate the support of CNPq. We would also like to express our heartfelt gratitude to the late Dr. Ricardo Koury, Professor at Federal University of Minas Gerais and dear friend, who provided his exceptional insight and expertise while assisting us on our research.

\section{References}

Aprea, C., Maiorino, A., 2009. Heat rejection pressure optimization for a carbon dioxide split system: an experimental study. Appl. Energy 86, 2373-2380.

ASHRAE, 2000. Ashrae guideline 12-2000: Minimizing the risk of legionellosis associated with building water systems. Atlanta (GA): ASHRAE.

ASHRAE, 2013. 2013 ASHRAE Handbook - Fundamentals (SI Edition). American Society of Heating, Refrigerating and Air-Conditioning Engineers, Inc.

ASME, 2009. V.\&V. 20-2009. Standard for verification and validation in computational fluid dynamics and heat transfer.

Belman-Flores, J.M., Rodriguez-Munoz, A., Pérez-Reguera, C.G., Mota-Babiloni, A., 2017. Experimental study of r1234yf as a drop-in replacement for r134a in a domestic refrigerator. Int. J. Refrig. 81, 1-11.

BIPM, I., IFCC, I., IUPAC, I., ISO, O., 2008. Evaluation of measurement data-guide for the expression of uncertainty in measurement. JCGM 100: 2008, 1-120.

Bodansky, D., 1993. The United Nations Framework Convention on Climate Change: A Commentary, vol. 18, HeinOnline.

Botticella, F., Viscito, L., 2015. Seasonal performance analysis of a residential heat pump using different fluids with low environmental impact. Energy Proc. 82, 878-885.

Chaichana, C., Aye, L., Charters, W.W., 2003. Natural working fluids for solar-boosted heat pumps. Int. J. Refrig. 26, 637-643.

Chata, F.G., Chaturvedi, S., Almogbel, A., 2005. Analysis of a direct expansion solar assisted heat pump using different refrigerants. Energy Convers. Manage. 46, 2614-2624.

Chaturvedi, S., Abazeri, M., 1987. Transient simulation of a capacity-modulated, direct-expansion, solar-assisted heat pump. Sol. Energy 39, 421-428.

Chaturvedi, S.K., Shen, J.Y., 1984. Thermal performance of a direct expansion solar-assisted heat pump. Sol. Energy 33, 155-162.

Chow, T.T., Pei, G., Fong, K., Lin, Z., Chan, A., He, M., 2010. Modeling and application of direct-expansion solar-assisted heat pump for water heating in subtropical hong kong. Appl. Energy 87, 643-649.

Chyng, J., Lee, C., Huang, B., 2003. Performance analysis of a solar-assisted heat pump water heater. Sol. Energy 74, 33-44.

Davies, T.W., Caretta, O., 2004. A low carbon, low TEWI refrigeration system design. Appl. Therm. Eng. 24, 1119-1128.

Deng, W., Yu, J., 2016. Simulation analysis on dynamic performance of a combined solar/ air dual source heat pump water heater. Energy Convers. Manage. 120, 378-387.

Diniz, H.A.G., 2017. Estudo comparativo da eficiência energética de uma bomba de calor assistida por energia solar operando com condensadores por imersão e coaxial. Master's thesis. UFMG.

Duarte, W.M., 2018. Numeric model of a direct expansion solar assisted heat pump water heater operating with low GWP refrigerants (R1234yf, R290, R600a and R744) for replacement of R134a. Ph.D. thesis. UFMG.

Duarte, W.M., Diniz, H.A.G., Paulino, T.F., Rabelo, S.N., Machado, L., 2018. Performance comparison of direct expansion solar assisted heat pump working with R1234yf as a drop-in replacement for R134a. In: 17th Brazilian Congress of Thermal Sciences and Engineering, $\mathrm{ABCM}$

Duffie, J.A., Beckman, W.A., 2013. Solar Engineering of Thermal Processes. John Wiley \& Sons.

Faria, R.N., Nunes, R.O., Koury, R.N.N., Machado, L., 2016. Dynamic modeling study for a solar evaporator with expansion valve assembly of a transcritical $\mathrm{CO}_{2}$ heat pump. Int. J. Refrig. 64, 203-213.

Fernández-Seara, J., neiro, C.P., Dopazo, J.A., Fernandes, F., Sousa, P.X., 2012. Experimental analysis of a direct expansion solar assisted heat pump with integral storage tank for domestic water heating under zero solar radiation conditions. Energy Convers. Manage. 59, 1-8.

Ghoubali, R., Byrne, P., Miriel, J., Bazantay, F., 2014. Simulation study of a heat pump for simultaneous heating and cooling coupled to buildings. Energy Build. 72, 141-149.

Gnielinski, V., 1976. New equations for heat and mass transfer in turbulent pipe and channel flow. Int. Chem. Eng. 16, 359-368.

Hanlon, P.C., 2001. Compressor Handbook. McGraw-Hill.

Hawlader, M., Chou, S., Ullah, M., 2001. The performance of a solar assisted heat pump water heating system. Appl. Therm. Eng. 21, 1049-1065.
Hughmark, G., 1965. Holdup and heat transfer in horizontal slug gas-liquid flow. Chem. Eng. Sci. 20, 1007-1010.

Islam, M.R., Sumathy, K., Gong, J., Khan, S.U., 2012. Performance study on solar assisted heat pump water heater using $\mathrm{CO}_{2}$ in a transcritical cycle. In: International Conference on Renewable Energies and Power Quality.

Ito, S., Miura, N., Wang, K., 1999. Performance of a heat pump using direct expansion solar collectors. Sol. Energy 65, 189-196.

Kim, S.C., Won, J.P., Kim, M.S., 2009. Effects of operating parameters on the performance of a $\mathrm{CO}_{2}$ air conditioning system for vehicles. Appl. Therm. Eng. 29, 2408-2416.

Kong, X., Jiang, K., Dong, S., Li, Y., Li, J., 2018. Control strategy and experimental analysis of a direct-expansion solar-assisted heat pump water heater with r134a. Energy 145, $17-24$

Kong, X., Li, Y., Lin, L., Yang, Y., 2017. Modeling evaluation of a direct-expansion solar-assisted heat pump water heater using r410a. Int. J. Refrig. 76, 136-146.

Kong, X., Sun, P., Dong, S., Jiang, K., Li, Y., 2018. Experimental performance analysis of a direct-expansion solar-assisted heat pump water heater with r134a in summer. Int. J. Refrig. 91, 12-19.

Kong, X., Zhang, D., Li, Y., Yang, Q., 2011. Thermal performance analysis of a direct-expansion solar-assisted heat pump water heater. Energy 36, 6830-6838.

Kuang, Y., Wang, R., 2006. Performance of a multi-functional direct-expansion solar assisted heat pump system. Sol. Energy 80, 795-803.

Kuang, Y.H., Sumathy, K., Wang, R.Z., 2003. Study on a direct-expansion solar-assisted heat pump water heating system. Int. J. Energy Res. 27, 531-548.

Lee, Y., Jung, D., 2012. A brief performance comparison of r1234yf and r134a in a bench tester for automobile applications. Appl. Therm. Eng. 35, 240-242.

Liao, S., Zhao, T., Jakobsen, A., 2000. A correlation of optimal heat rejection pressures in transcritical carbon dioxide cycles. Appl. Therm. Eng. 20, 831-841.

Ma, Y., Liu, Z., Tian, H., 2013. A review of transcritical carbon dioxide heat pump and refrigeration cycles. Energy 55, 156-172.

Makhnatch, P., Khodabandeh, R., 2014. The role of environmental metrics (GWP, TEWI, LCCP) in the selection of low GWP refrigerant. Energy Proc. 61, 2460-2463.

Makhnatch, P., Khodabandeh, R., 2014b. Selection of low GWP refrigerant for heat pumps by assessing the life cycle climate performance (LCCP). In: 11th International Energy Agency Heat Pump Conference Montreal, May 12-16, 2014.

Minetto, S., 2011. Theoretical and experimental analysis of a $\mathrm{CO}_{2}$ heat pump for domestic hot water. Int. J. Refrig. 34, 742-751.

Mohamed, E., Riffat, S., Omer, S., 2017. Low-temperature solar-plate-assisted heat pump: a developed design for domestic applications in cold climate. Int. J. Refrig. 81, 134-150.

Mohanraj, M., Belyayev, Y., Jayaraj, S., Kaltayev, A., 2018. Research and developments on solar assisted compression heat pump systems-a comprehensive review (part a: Modeling and modifications). Renew. Sustain. Energy Rev. 83, 90-123.

Moreno-Rodriguez, A., Garcia-Hernando, N., González-Gil, A., Izquierdo, M., 2013. Experimental validation of a theoretical model for a direct-expansion solar-assisted heat pump applied to heating. Energy 60, 242-253.

Neils, G., Klein, S., 2009. Heat Transfer. Cambridge university press.

Oliveira, R.N., Faria, R.N., Antonanzas-Torres, F., Machado, L., Koury, R.N.N., 2016. Dynamic model and experimental validation for a gas cooler of a $\mathrm{CO}_{2}$ heat pump for heating residential water. Sci. Technol. Built Environ. 22, 30-40.

Omojaro, P., Breitkopf, C., 2013. Direct expansion solar assisted heat pumps: a review of applications and recent research. Renew. Sustain. Energy Rev. 22, 33-45.

Palm, B., 2008. Hydrocarbons as refrigerants in small heat pump and refrigeration systems-a review. Int. J. Refrig. 31, 552-563.

Paradeshi, L., Srinivas, M., Jayaraj, S., 2016. Parametric studies of a simple direct expansion solar assisted heat pump operating in a hot and humid environment. Energy Proc. 90, 635-644.

Paradeshi, L., Srinivas, M., Jayaraj, S., 2018. Performance of hydrocarbon mixture in a direct expansion solar assisted heat pump system. Heat Mass Transf. 1-13.

Qi, P.C., He, Y.L., Wang, X.L., Meng, X.Z., 2013. Experimental investigation of the optimal heat rejection pressure for a transcritical $\mathrm{CO}_{2}$ heat pump water heater. Appl. Therm. Eng. 56, 120-125.

Reis, R.V.d.M., 2012. Análise experimental comparativa entre uma bomba de calor e uma resistência elétrica como dispositivo de apoio de energia para um aquecedor solar de água. Ph.D. thesis. UFMG.

Rohsenow, W.M., Hartnett, J.P., Cho, Y.I., et al., 1998. Handbook of Heat Transfer, vol. 3 , McGraw-Hill, New York.

Sarbu, I., 2014. A review on substitution strategy of non-ecological refrigerants from vapour compression-based refrigeration, air-conditioning and heat pump systems. Int J. Refrig. 46, 123-141.

Sarkar, J., Bhattacharyya, S., Gopal, M.R., 2004. Optimization of a transcritical $\mathrm{CO}_{2}$ heat pump cycle for simultaneous cooling and heating applications. Int. J. Refrig. 27 830-838.

Shah, M.M., 2016. Comprehensive correlations for heat transfer during condensation in conventional and mini/micro channels in all orientations. Int. J. Refrig. 67, 22-41.

Shah, M.M., 2017. Unified correlation for heat transfer during boiling in plain mini/micro and conventional channels. Int. J. Refrig. 74, 604-624.

Sun, X., Dai, Y., Novakovic, V., Wu, J., Wang, R., 2015. Performance comparison of direct expansion solar-assisted heat pump and conventional air source heat pump for domestic hot water. Energy Proc. 70, 394-401.

Sun, X., Wu, J., Dai, Y., Wang, R., 2014. Experimental study on roll-bond collector/evaporator with optimized-channel used in direct expansion solar assisted heat pump water heating system. Appl. Therm. Eng. 66, 571-579.

Tsamos, K., Ge, Y., Santosa, I., Tassou, S., Bianchi, G., Mylona, Z., 2017. Energy analysis of alternative $\mathrm{CO}_{2}$ refrigeration system configurations for retail food applications in moderate and warm climates. Energy Convers. Manage.

UNEP, 2006. Handbook for the montreal protocol on substances that deplete the ozone layer.

UNEP, 2015. 2014 Report of the Refrigeration, Air Conditioning and Heat Pumps Technical Options Committee. Technical Report. UNEP. 
Wang, S., Tuo, H., Cao, F., Xing, Z., 2013. Experimental investigation on air-source transcritical $\mathrm{CO}_{2}$ heat pump water heater system at a fixed water inlet temperature. Int. J. Refrig. 36, 701-716.

Xu, G., Deng, S., Zhang, X., Yang, L., Zhang, Y., 2009. Simulation of a photovoltaic/ thermal heat pump system having a modified collector/evaporator. Sol. Energy 83, 1967-1976.
Xu, X., Hwang, Y., Radermacher, R., 2013. Performance comparison of R410A and R32 in vapor injection cycles. Int. J. Refrig. 36, 892-903.

Yang, L., Li, H., Cai, S.W., Shao, L.L., Zhang, C.L., 2015. Minimizing COP loss from optimal high pressure correlation for transcritical $\mathrm{CO}_{2}$ cycle. Appl. Therm. Eng. 89, 656-662. 